\title{
Clonality as a key but overlooked driver of biotic interactions in plants
}

\author{
Anne-Kristel Bittebiere ${ }^{\mathrm{a},{ }^{*}}$, Marie-Lise Benot ${ }^{\mathrm{b}}$, Cendrine Mony $^{\mathrm{c}}$
}

(a) LEHNA, CNRS - University of Lyon 1, 43 Boulevard du 11 Novembre 1918, 69622 Villeurbanne Cedex, France, anne-kristel.bittebiere@univ-lyon1.fr; (b) BIOGECO, Univ. Bordeaux, INRA, 33615 Pessac, France, marie-lise.benot@u-bordeaux.fr; (c) UMR 6553 ECOBIO, CNRS - University of Rennes, Av. du Général Leclerc, 35042 Rennes Cedex, France, cendrine.mony@ univ-rennes1.fr.

*Corresponding author

\section{Highlights}

- Clonal traits drive not only the individual plant fitness, but also the whole plant community assembly and ecosystem functioning through their involvement in plant biotic interactions with other micro- and macro-organisms.

- Clonality influences a wide range of processes in space and over time, and subsequently affects biotic interactions.

- Clonal traits are thus not only response traits but also effect traits for plant biotic interactions with other organisms (plants, herbivores, pollinators, and fungi).

\begin{abstract}
Most plants are clonal i.e. able to laterally propagate by producing new genetically identical ramets connected by specialized clonal organs. Clonality determines ramet aggregation patterns, the presence of physical connections between ramets, the sharing of resources, hormones, and signaling molecules within the clonal fragment. We thus argue that clonal traits drive not only the individual plant fitness, but also the whole plant community assembly and ecosystem functioning through their involvement in plant biotic interactions with other microand macro-organisms. In an extensive literature review, we investigated how clonality influences a wide range of processes in space and over time, and subsequently affects biotic interactions. These processes occur both at the plant and the population levels, including spatial patterns of below- and aboveground organs, micro-environmental heterogeneity and genetic diversity. We highlight the responses of clonal plant traits to biotic interactions, and reciprocally, the effects of clonality on plant-plant, plant-animal (with herbivores, pollinators), and plant-microorganism interactions (with pathogens, mutualists). Based on this knowledge,
\end{abstract}


we suggest future prospects are promising, in particular if clonal traits are integrated in studies of multitrophic level interactions, thereby enabling a new understanding of plant community assembly rules and the ability to predict changes in biodiversity due to modifications in biotic interactions.

Keywords: Clonal plants; Plant community assembly; Response-effect traits; Spatial patterns.

\section{Introduction}

Although plants are sessile organisms, they form the basis of complex interaction networks (Jordano et al., 2002; Pieterse and Dicke, 2007; Thébault and Fontaine, 2010; Toju et al., 2014). In turn, these interactions affect the presence and abundance of plant species and hence play a significant role in plant community assembly. Complex networks of interacting species have received increased attention in the past decade (Proulx et al., 2005). Investigations of the underlying mechanisms strongly benefitted from trait-based approaches mainly focused on resource acquisition traits (e.g. Ibanez et al., 2013; Kraft et al., 2015; Rillig et al., 2015) that made it possible to link species strategies and ecosystem functioning (Lavorel and Garnier, 2002). In particular, determining how interactions occur between different biodiversity compartments should enable mechanistic understanding of ecosystem processes including nutrient cycling, productivity, resilience to disturbances or resistance to invasion (Loreau et al., 2001). However, one difficulty in predicting the dynamics of plant species interactions with other plants, animals, and microorganisms is the fact that most of them are clonal (Klimeš et al., 1997). A large body of literature has already highlighted the role of clonality in biotic interactions (see e.g. Gómez and Stuefer, 2006; Benot et al., 2013; Vannier et al., 2018) and in ecosystem functioning (e.g. Bittebiere et al., 2013; Cornelissen et al., 2014). Yet, so far, the existence of general patterns of clonal traits in theories concerning the various processes of plant interactions with their biotic environment, has been overlooked.

Clonal plants can produce genetically identical and potentially independent ramets (erect shoots with leaves and roots) by vegetative growth (i.e. mitosis) (Harper, 1977; van Groenendael et al., 1996). All connected ramets form the "clonal fragment" (Eriksson and Jerling, 1990) while the "genet" corresponds to the set of genetically identical fragments produced by vegetative growth of the same zygote (Harper and White, 1974; Pan and Price, 2002). The individual definition then becomes fuzzy, as all these structures have different lifespans (Wildová et al., 2007). Allocation to clonal growth is known to depend on a trade-off 
with sexual reproduction (Eriksson, 1997; Piquot et al., 1998; Herben et al., 2015). The intensity of clonal growth is determined by the individual plant genotype (Fisher and van Kleunen, 2002), species (Eckert and Barrett, 1993) and by the environment (Stöcklin and Winkler, 2004). Klimeš et al. (1997) delineated a wide variety of clonal growth forms, although most species propagate clonally by producing their ramets along plagiotropic stems (rhizome or stolons), referred to as connections. The resulting network structure is characterized by its branching frequency, length of connections, and the duration of the connection. Variations in these characteristics confer particular properties to clonal plants that ultimately affect their performance. First, physical integration drives the horizontal propagation of the plant, whereby the clonal architecture describes a continuum from a loose (guerilla strategy) to an aggregated (phalanx strategy) arrangement of ramets. Long connections allow exploration of space whereas high branching density enhances occupation of space (Lovett Doust, 1981). Connections have varying lifespans, ranging from transient (splitter strategy) to long-lasting (integrator strategy); Oborny et al., 2001). Second, ramets can store resources or exchange them thanks to connections (Alpert and Stuefer, 1997; Stuefer and Huber, 1999). This physiological integration allows ramets to share information on the suitability of their environment, which may subsequently lead to variations in the horizontal architecture (Slade and Hutchings, 1987; de Kroon and Hutchings, 1995; Oborny and Cain, 1997) or vertical architecture (foliage, root specialization) (Price and Marshall, 1999; Alpert and Stuefer, 1997) of the clonal plant.

Clonal properties drive plant growth in space and over time, shaping the spatial patterns of both plant genetic diversity (Charpentier, 2002), and of the plant's vegetative and reproductive structures, which are resources or provide habitats for various organisms (Harper, 1977; Keddy, 2010). Additionally, clonal properties determine how the plant manages nutrient, water, and light resources (D’Hertefeld and Jónsdóttir, 1994; Price and Marshall, 1999; Alpert and Stuefer, 1997). Overall, these processes lead to environmental heterogeneity generated by the plant itself (Silvertown and Smith, 1989; Jackson and Caldwell, 1993; Herben et al., 2000) and may play a significant role in plant interactions with its biotic environment i.e. with other plants, animals, and microorganisms. Here, we review the role (response and effect) of clonality in a plant's interactions with its biotic environment (Fig. 1). The extensive literature on this subject indeed points to a synthesis that could provide the basis for further development and/or renewal of existing theories of plant community assembly and ecosystem functioning. Our review focuses on direct interactions involving clonal plants whose growth forms a network with stem connections. We present general theories on plant interactions and then elucidate how clonality is likely to modify the outcomes of the interactions. Additionally, we call for novel 
scientific questions linking clonality and multitrophic level interactions in particular, and hope our paper will encourage the integration of clonality in studies of plant community assembly and ecosystem functioning.

\section{Plant-plant interactions}

\section{Theory}

Competition results from a shared need for a limited resource (light, water, nutrients) leading to reduced fitness in at least one of the competing individual plants (Begon et al., 1996) (Box 1). Plant competitive ability is determined by its efficiency in capturing resources and suppressing other individuals (competitive effect), and in withstanding the negative effects of neighbors (competitive response) (Goldberg, 1987; 1990; Keddy et al., 1994). Competition for nutrients and water is symmetric. On the contrary, under size-asymmetric competition such as for light, larger individuals exploit disproportionately larger amounts of the resource than smaller individuals (Schwinning and Weiner, 1998; DeMalach et al., 2016). Facilitation is a positive interaction that benefits at least one of the participating plants (Bruno et al., 2003) (Box 1). Facilitating individuals locally improve stressful environmental conditions (e.g. temperature, water or nutrient availability), by creating suitable micro-habitats for the establishment of other individuals (Bertness and Callaway, 1994). As plants have a sessile lifestyle, competitive and facilitative interactions occur within their immediate neighborhood (Mack and Harper, 1977; Silander and Pacala, 1985; Murrell et al., 2001) i.e. the plant's eye view (Turkington and Harper, 1979). The process and outcome of competition between neighboring plants are related to mechanisms of niche stabilizing (limiting similarity in traits between neighbors) and of equalizing fitness (supporting competitive ability) (Chesson, 2000; HilleRisLambers et al., 2012; Turcotte and Levine, 2016). Indeed, according to the limiting similarity theory, species sharing the same niche cannot coexist (MacArthur and Levins, 1967), while competitive hierarchies determine which species should persist and even dominate the plant community, based on the ranking of the species competitive abilities (Keddy et al., 1994).

One central issue in ecology is explaining the paradoxically large number of species that coexist locally in plant communities (Klimeš, 1999). The spatial structure of plant communities has been suggested to be of particular importance in stable species coexistence (Tilman, 1994; Semchenko et al., 2013), by determining the plant's eye view (Turkington and Harper, 1979). Conspecifics tend to develop into aggregated spatial patterns segregated from other species, thereby increasing intraspecific competition relative to interspecific competition (Stoll and 
Prati, 2001; Semchenko et al., 2013) and reducing the probability of meeting individuals with higher competitive abilities. In addition to this spatial niche partitioning, Grubb (1977) emphasized the role of regeneration niches. Individual deaths create opportunities for new individuals to establish themselves in a recently vacated site. Another suggested mechanism of species coexistence is the life-history trade-off between colonization and competition: good competitors are hypothesized to be poor colonizers and vice versa (Tilman, 1994).

As clonality is ubiquitous (Klimeš et al., 1997), most interactions within plant communities involve clonal plants. Clonal growth traits have been shown to be able to predict local species abundance (Herben et al., 2014) i.e. interaction outcomes. These traits are indeed involved in particular interaction processes likely determining the effects of clonal growth on species performances and coexistence.

\section{Spatio-temporal scale of clonal plant response to plant-plant interactions}

Unlike non-clonal plants, physically integrated and genetic individuals are decoupled in clonal plants. Additionally, the physically integrated individual (hereafter referred as to the "clonal fragment") is subdivided into potentially autonomous units, i.e. ramets (Pan and Price, 2002), which may eventually flower. The balance between sexual reproduction and clonal growth is affected by competition. In Ranunculus reptans, allocation to sexual reproduction increases more than allocation to clonal growth under higher competitive density (van Kleunen et al., 2001). Moreover, clonal plants spend a lot of energy on competition between mother and genetically identical (daughter) ramets. The probability of self-competition should then influence selection for sexuality instead of clonality (Zobel, 2008).

Ramets and clonal fragments perceive their neighborhood and its heterogeneity at different spatial scales. From the "fragment's-eye view", the biotic environment is heterogeneous whereas the ramet spends its life in one homogeneous micro-environment (Turkington et al., 1991). Depending on its neighbors, the ramet experiences intra-clonal fragment, intra-genet, and inter-genet interactions (Fig. 2). As clonal propagation places offspring in the vicinity of their mother, ramets are likely to meet related individuals (intragenet interactions) (Turkington and Harper, 1979; Lovett Doust, 1981). Avoidance of competition between neighboring ramets would then be favored while kin selection should be particularly strong, as they are genetically identical (Semchenko et al., 2013). Physiological integration is then suggested as a mechanism supporting intraclonal regulation of interaction effects (Derner and Briske, 1999) through self/non-self discrimination (Herben and Novoplansky, 2008), and through the control of daughter ramet production (Jónsdóttir and 
Callaghan 1988; Callaghan et al., 1992) and of mother ramet mortality (Carlsson and Callaghan, 1990), shifting competition from the ramet to the fragment scale. In parallel, de Kroon et al. (1992) concluded through an experiment conducted on the rhizomatous species Carex flacca and Brachypodium pinnatum that competition between ramets on the one hand, and clonal fragments on the other hand, are respectively asymmetric and symmetric. Overall, these two mechanisms generate long-lasting and self-sustaining clonal phalanx structures (Herben and Novoplansky, 2008). Physiological integration also affects the competitive response of a ramet to its own neighborhood, as this response is averaged relatively to all neighborhoods perceived by the other connected ramets (Hartnett and Bazzaz, 1985; Turkington et al., 1991) (Table 1). The response of integrator species to plant community composition should thus be determined at the scale of the clonal fragment rather than at the ramet scale.

Even if herbaceous ramets live for an average of two years (Sammul et al., 2003), fragments may live longer (Wildová et al., 2007), leading to a notable discrepancy between ramet and fragment time scales of interaction. The corollary is that responses to plant-plant interactions should not be considered at an annual timescale (Hartnett and Bazzaz, 1985). In particular, the clonal fragment builds a competitive experience over the years. Its horizontal and vertical traits are indeed adjusted according to its local past and present neighborhoods (Bittebiere and Mony, 2015) (Table 1). This competitive experience relies on information about the quality and variability of the environment, which is sampled and then shared between connected ramets, inducing modifications in horizontal spreading (i.e. internode length) of the clonal plant (Louâpre et al., 2012). In Trifolium repens, Turkington et al. (1991) demonstrated that clonal fragment growth in mixtures with competitors of different identities under controlled conditions depended on the species previously associated with T. repens fragments in situ. These differences among clonal fragments may not be truly genetic as they are reversible over time (Turkington et al., 1991) but rather related to the transmission of plastic responses to competition to the following generation of ramets.

\section{Clonal plant response to competition is three-dimensional}

As clonal plants grow vertically (ramets) but also horizontally (connections), interactions between plant vegetative parts are dual in nature: competitive ability ranking between close neighbors, and occupation of the horizontal space (Herben and Hara, 1997). Traits linked to resource acquisition or use (i.e. ramet traits) determine competitive ability and hence competitive hierarchies between neighbors, while certain, architectural traits (internode length, branching angle) involved in clonal propagation, determine spatial niche partitioning by 
allowing spatial segregation (Herben and Goldberg, 2014). Plastic responses of clonal traits to biotic interactions thus play varying roles in the equalizing and stabilizing mechanisms of coexistence (Herben and Goldberg, 2014). First, plastic adjustments to the biotic neighborhood occur in the horizontal direction. Clonal plants can grow in the direction of least interference by positioning their ramets in less densely occupied patches (de Kroon and Hutchings, 1995; Oborny and Cain, 1997; Herben and Novoplansky, 2010) (Table 1). Using a modeling approach, Herben and Novoplansky (2010) showed that this avoidance response is especially adaptive at low competitor density. Plastic modifications of the clonal architecture allowing competitive avoidance are triggered by environmental cues such as low R:FR ratio (Leeflang, 1999; Marcuvitz and Turkington, 2000), informing the individual plant of the presence of competitors. Similar plastic responses likely occur in facilitative interactions, with clonal growth directed towards plants that locally enhance microenvironmental conditions. Examples illustrating this hypothesis are still rare in the literature (Table 2). Through field observations, Cornacchia et al. (2018) found that two clonal macrophyte species aggregate around Callitriche platycarpa, generating heterogeneity in the hydrodynamic conditions and hence locally reducing hydraulic stress. Although these authors did not explicitly test it, we would expect clonal growth to be responsible for the particular spatial arrangement of macrophyte species. Directionality in clonal growth, referred to as foraging, relies on modifications of the clonal architecture with either increasing (Price and Hutchings, 1996) or decreasing internode lengths depending on the species considered (Sutherland and Stillman, 1988; Cheplick, 1997), and with variations in the branching angle and frequency (Cain, 1994; Oborny and Cain, 1997). Second, in the vertical direction, ramets can optimize the morphology of their resource acquiring organs (e.g. petiole elongation, increase in leaf area or biomass allocation to roots) (Callaway et al., 2003; Weijschedé et al., 2008; Bittebiere et al., 2012). Aside from these architectural responses, biotic interactions modify plant resource management strategies (Table 1). As biotic interactions generate fine-scale heterogeneity, they should favor integrator species (Oborny et al., 2000; Herben, 2004) able to establish new ramets in unfavorable patches (D'Hertefeld and Jónsdóttir, 1994; Stuefer et al., 1994; Gough et al., 2002). Carbohydrates stored in connection tissues also help the plant develop its leaves and preempt space in the canopy (access to the light resource) (Grime, 2001). Several studies highlighted the fact that biomass allocation to reserve organs (rhizomes, roots) increases under competition (Cheplick, 1997; Cheplick and Gutierrez, 2000).

The competitive responses of both vertical and horizontal clonal traits are determined relative to plant community richness (Bittebiere et al., 2019). Higher species richness indeed 
triggers an increase in clonal trait variability, which reflects the wide range of competitive responses deployed when plants are faced with many different competitor identities. The adaptive character of these plastic modifications depends on the density of neighbors (Bittebiere et al., 2014).

\section{Effect of clonal mobility on species coexistence}

Clonal mobility i.e. the ability to move in space using vegetative organs (Tamm et al., 2002; Zobel et al., 2010) has strong species-specific components and in addition, is modulated by the biotic and abiotic environment of the plant (Klimeš, 1999; Sammul et al., 2003). Nevertheless, it mainly remains under the influence of the plant clonal growth strategy: guerilla vs. phalanx (Lovett Doust, 1981; Benot et al., 2013).

First, clonal mobility determines the species spatial pattern formation at a fine scale (a few centimeters) (Pottier and Evette, 2010; Benot et al., 2013) and then contributes to the spatial structure of plant communities. Spatial patterns result in vegetation-induced heterogeneity in the biotic environment (competition intensity, neighbors identity) as well as in the abiotic environment (resource spatial distribution) of the ramet (Jackson and Caldwell, 1993; Herben et al., 2000) leading to varying - either positive or negative - interactions with neighbors (Fig. 3). In an experimental study involving four herbaceous clonal species, Bittebiere et al. (2012) demonstrated that neighbor identities and more specifically their clonal growth strategies, determine the intensity and heterogeneity of competition. These values are especially important in the competitive balance between phalanx and guerilla species, respectively favored under homogeneous and heterogeneous conditions (Lovett Doust, 1981; Humphrey and Pike, 1998). Conversely, ring (Bonanomi et al., 2014) or patchy structures in rivers (Cornacchia et al., 2018) both resulting from the spread of clonal plants, create specialized niches (suitable microhabitats) to colonize. By locally increasing nutrient resources (Derner and Briske, 1999; 2001; Cornelissen et al., 2014) or decreasing stream flow (Cornacchia et al., 2018), they behave as nurse plants that allow the establishment of heterospecifics.

Second, clonal mobility at least partially explains the temporal dynamics of plant species spatial patterns (Herben et al, 1994; Wildová et al., 2007; Zobel et al., 2010) so that initial patterns resulting from seed dispersal become less relevant in determining the outcome of species interactions over time (Schmid and Harper, 1985). This local turnover of species may be an outcome of the competition-colonization trade-off. Theoretically, in the longer term, ramets of rapid colonizers (guerilla species) die, leaving gaps, i.e. regeneration niches, for the establishment of slower colonizers but with higher competitive abilities, which will then occupy the space for a longer time (phalanx species) (Wildová et al., 2007; Zobel et al., 2010). 
Nevertheless, an experimental test of this assumption only partially supported it, likely because the experiment was too short to observe the progression of phalanx species (Saiz et al., 2016).

Clonal mobility thus strongly interferes with mechanisms of species coexistence so that local between-species variations in clonal mobility have been shown to enhance small-scale richness in grassland communities (Schmid and Harper, 1985; Herben et al., 1994; Moora et al., 2009).

\section{Plant-herbivore interactions}

\section{Theory}

Herbivory corresponds to the consumption by animals (herbivores) of plant material and concerns every plant organ, either below- or aboveground (Box 1). It occurs in a wide range of animal taxa, including insects, birds and mammals (Huntly 1991). In the case of large mammalian herbivores, plant biomass consumption is usually coupled with trampling, urine and faeces deposition, as a result of herbivore activity and movement during grazing. Biomass consumption is considered to be the most important grazing component affecting plants (Kohler et al., 2004). Belowground herbivory can also play an important role in plant community dynamics (van der Putten, 2003). Herbivory is thus a complex interaction that affects individual plants and plant communities in several ways. For the purpose of clarity, in this section, plantherbivore interactions are almost only considered as defoliation, which usually describes loss of leaf biomass, but may also involve other aboveground organs. At the plant scale, herbivory has either direct or indirect effects by modifying the plant biotic and abiotic environment (Hulme, 1996). At the community level, herbivory is known to modify species diversity and composition, particularly by modifying the balance between competition and colonization (Bakker et al., 2006). Herbivory has contrasted effects on community diversity (Milchunas et al., 1998), due to several features linked to herbivore pressure, e.g. the organ and the proportion of biomass removed or the timing of herbivory, which varies depending on the type, selectivity, size and abundance of herbivores (Huntly, 1991; Olff and Ritchie, 1998). Changes in species composition result from contrasting plant responses to herbivory. Plant resistance includes mechanisms that enable the plant to survive, develop and reproduce under herbivore pressure. Resistance is divided into avoidance, which encompasses defense together with spatial and temporal avoidance, and tolerance (Briske, 1996) (Box 1). Avoidance and tolerance have often been considered as alternative strategies of plant response to herbivory (van der Meijden et al., 
1988; Strauss and Agrawal, 1999) and can be either constitutive or induced by previous herbivory. Induced responses rely on the transport of damage signals and involve several mechanisms including increased concentrations of secondary metabolites, physiological, anatomical or morphological changes and can be expressed at different scales, ranging from very local (e.g., leaves) to systemic (e.g., whole plant parts to the whole plant) responses (Karban and Myers, 1989).

Plant strategies of response to herbivory can also be expressed at the plant assemblage level. Selectivity of herbivores implies that vegetation characteristics, particularly diversity, composition and the spatial arrangement of the plant assemblage, orient their feeding behavior (Milchunas and Noy-Meir, 2002). The consequences of plant diversity and spatial arrangement for herbivores are generally linked to plant functional traits (e.g., traits that govern palatability, but also plant apparency, Milchunas and Noy-Meir, 2002; Castagneyrol et al., 2013) as well as phylogenetic (Castagneyrol et al., 2014) or genetic diversity (Castagneyrol et al., 2012). The diversity of a plant assemblage may be differently perceived by herbivores depending on their degree of specialization for the resource. For specialist herbivores, dense pure stands of the preferred resource would be easier to detect (resource concentration hypothesis, Root, 1973). On the contrary, they could result in the dilution of herbivores within the stand thereby reducing the use of each resource unit (host plant) than when it is sparsely distributed, especially when the potential number of herbivores is limited (Yamamura, 2002; Otway et al., 2005). Diverse plant assemblages increase overall resource quality for generalist herbivores (e.g. nutrient complementarity hypothesis, Rapport, 1980; Unsicker et al., 2008). Associational resistance theory then suggests that plant diversity reduces herbivory of a specific plant, as it is less detectable by herbivores (Tahvanainen and Root, 1972). In particular, associational avoidance includes mechanisms by which a plant benefits from either unpalatable neighbors that reduce the attractiveness of the patch of vegetation (Callaway et al., 2000) or, on the contrary, from more palatable neighbors that attract herbivores and divert them from the focal plant (Milchunas and Noy-Meir, 2002). Alternatively, contagion by neighboring plants could increase the probability of a less preferred plant being attacked, especially in the case of high herbivore density (associational susceptibility, White and Whitham, 2000). Finally, induced plant responses to herbivory can also have consequences at the plant assemblage and higher trophic levels, through the emission of complex mixtures of volatile compounds that elicit defense induction in undamaged plants, with significant effects on plant fitness (Dicke et al., 2003), and act as cues for herbivore enemies (mostly predatory arthropods and parasitoids, McCormick et al., 2012). The response of plants to neighboring signals has been observed within species (e.g., 
Dolch and Tscharntke, 2000) as well as between different species (e.g., Karban et al., 2000; 2003), probably because herbivore-induced volatile compounds are generally consistent among species. Nevertheless, interspecific variations in their relative amounts could contribute to the specificity of this plant-plant communication (McCormick et al., 2012). Additionally, emitted substances can vary in response to different herbivores (McCormick et al., 2012 and references therein). Although mostly studied aboveground, such plant-plant communication can also be mediated via the belowground compartment (see Dicke et al., 2003 and references therein).

Due to their ubiquity in several ecosystems and especially in herbaceous vegetation, clonal plants are likely to be under pressure from several types of herbivores ranging from small invertebrates to large mammals. These may interact with clonal plants in different ways and at different scales, especially regarding the type of organ, amount and spatial pattern of biomass consumed.

\section{Responses of clonal plants to herbivory}

Studies that have investigated plant-herbivore interactions include experiments involving herbivores themselves (e.g. field experiments along gradients of herbivore pressure, experimental exposure to herbivores) or experimental biomass removal (clipping) to mimic the effect of herbivores. Depending on the study, measurements can be made either at the clonal fragment or at the community level (i.e. assemblage of potentially numerous clonal fragments of a single or of several species).

The consequences of herbivory for clonal multiplication rates are contrasted and still poorly understood. They range from positive (e.g. Jónsdóttir, 1991; Dalgleish and Hartnett, 2009) to no effects (e.g. Beaulieu et al., 1996, Bråthen and Junttila, 2006), or negative effects on the number or density of ramets (e.g. Bråthen and Junttila, 2006; Gao et al., 2014; Dong et al., 2017), all three types of responses have even been recorded in a single species i.e., Carex bigelowii (Jónsdóttir, 1991; Bråthen and Junttila, 2006). Long connections (guerilla strategy) are suggested to allow the plant to escape herbivory (spatial avoidance strategy) in response to damage inflicted below ground (van der Putten, 2003 and references therein). Contrarily, aboveground defoliation generally results in maintained or reduced connection and internode length (Hay and Newton, 1996; Moen and Walton, 1996; Moen et al., 1999; Li et al., 2005; Benot et al., 2009; Gao et al., 2014), suggesting that spatial avoidance through lateral spread is not an efficient strategy in response to larger or more mobile aboveground herbivores (Table 1). These changes are occasionally enhanced by increased branching densities (Moen et al., 1999; Li et al., 2005) and generate compact clonal architectures. Belowground connections may 
also contribute to spatial avoidance of aboveground herbivory (Klimešová and Klimeš, 2007), although this hypothesis has only little or inconsistent support (see e.g., Benot et al. 2011).

Clonality also affects the role and distribution of defenses (Table 1). Defenses are not uniformly allocated to connected ramets varying e.g. between phenological stages (Bråthen et al., 2004; Gómez and Stuefer 2006). In the rhizomatous sedge Carex stans, defenses are preferentially allocated to flowering rather than to vegetative ramets (Bråthen et al., 2004). As flowering ramets are a priori more valuable in terms of future reproduction, these results agree with expectations concerning optimal defense distribution in the plant (McKey, 1974; Bråthen et al., 2004). However, they are not fully in accordance with the actual feeding behavior of lemmings, which differs between study sites and may even be directed towards flowering ramets (Bråthen et al., 2004). On the contrary, younger ramets of Trifolium repens contain different phenolic mixtures, have tender leaves and are of higher nutritive value and are more attractive to caterpillars of Spodoptera exigua than older leaves (Gómez and Stuefer, 2006; Gómez et al. 2008), even though those ramets are more valuable in terms of future vegetative growth and reproduction potential than older ones. Whether the constitutive distribution of defenses among ramets is an efficient strategy to avoid herbivory thus remains to be clarified.

As resources stored in clonal organs have been shown to support plant growth after disturbances (Iwasa and Kubo, 1997; Kleijn et al., 2005; Asaeda et al., 2006), clonal storage would be favored in environments with high risks of herbivory. On the contrary, Benot et al. (2011) reported that clonal plant species in grazed grasslands mostly produced either short below-ground connections or short-lived aboveground connections (Table 1). This suggests that the costs of production and maintenance of long-distance spreading or long-lived connections, which may store resources available to resume growth after damage, outweigh their possible benefits. More precisely, several studies reported either the depletion of carbohydrate reserves stored in clonal organs (Beaulieu et al., 1996; Dong et al., 2017) or reduced investment in storage organs, e.g. tuber mass and size (Piqueras, 1999a; Li et al., 2004), stolon and rhizome mass (Moen and Walton, 1996; Li et al., 2004; Wang et al., 2004; Liu et al., 2009; Mohammad Esmaeili et al., 2009) in response to real or simulated herbivory. Whether these decreases in carbohydrate reserves or in the biomass of storage organs support compensatory growth and hence, tolerance to herbivory, remains unclear. First, depletion of carbohydrate reserves was accompanied by the compensation for leaf loss and net aboveground production in the rhizomatous sedge Eriophorum scheuchzeri (Beaulieu et al., 1996), whereas the reverse was observed in the stoloniferous perennial herb Alternanthera philoxeroides (Dong et al., 2017). Second, the decrease in biomass in clonal storage organs is generally linked to an overall 
decrease in total biomass. These patterns are less clear when relative biomass allocation rather than absolute biomass is considered, responses to defoliation then range from decreases (Mohammad Esmaeili et al., 2009), no changes (Moen and Walton, 1996; Li et al., 2004; Mohammad Esmaeili et al., 2009), to increases (Moen and Walton, 1996), depending on the organ, species or habitat considered. Thus, the overall negative effects of herbivory on the biomass of clonal organs are often simply due to allometric effects, rather than to the actual reallocation of reserves to support plant tolerance to herbivory. Further investigations are thus necessary to test whether (1) the formation of reserves in specialized clonal organs and remobilization are effective strategies of tolerance to herbivory, and (2) plants allocating biomass in the form of large reserve pools in those storage organs are favored in environments with a high risk of herbivory, in particular in regard with the predictability, intensity and spatial pattern of herbivory.

\section{Clonal integration and response to herbivory: resource sharing and defense signaling}

Physiological integration enables the transport of resources as well as non-resource substances among ramets and may thus be involved either in herbivory tolerance or avoidance strategies (Table 1). The role of physiological integration in tolerance to defoliation induced by herbivores has long been suggested (Herms and Mattson, 1992). By supporting resource translocation from storage clonal organs or undamaged ramets, to damaged ones, physiological integration would help the whole clonal fragment to tolerate herbivory. This hypothesis finds contrasted support in several studies based either on comparisons of clonal and non-clonal species or on experimental severing of clonal connections. The presence of intact connections alleviates the negative effects of defoliation on the clonal fragment biomass and the production of new ramets (Liu et al., 2007; 2009), while an absence of effect was also reported, both at the clonal fragment and ramet level (Wilsey, 2002; Wang et al., 2004; Liu et al., 2009). These contrasting results can be explained by different experimental conditions and different variables measured, but they also suggest that physiological integration supports tolerance to herbivory only in some situations. In particular, the efficiency of physiological integration is linked to the scale and spatial pattern of defoliation, as resource transport from undamaged to damaged ramets within phloem is constrained by vascular architecture and directional sap flow (Price and Hutchings, 1992).

Induced defense in response to herbivory occurs in clonal plants where it is supported by the transport of defense signaling compounds through clonal connections (Table 1). The transport of signals and the efficiency of induced responses are affected by the spatial pattern 
of herbivory (Gómez and Stuefer, 2006). As the translocation of defense signaling substances from damaged to undamaged ramets mainly follows phloem sap flow, defense induction within a clonal fragment is governed by source-sink relationships. In Trifolium repens, herbivore attacks on older ramets induced nutritive and biomechanical changes in younger ramets, thereby decreasing damage to their leaves (Gómez and Stuefer, 2006; Gómez et al., 2008). Similar results were obtained in the rhizomatous sedge Carex atrofusca after induction by jasmonic acid (Chen et al., 2011). Contrary to the emission of volatile compounds inducing responses in conspecifics and even plants belonging to different species, the transmission of defense signaling through clonal connections is restricted and consequently benefits only the clonal fragment, i.e. related ramets. Whether intra-clonal defense signaling is more advantageous to clonal plants than to non-clonal ones, as well as its effective distance and timing is not yet known and thus deserves more attention.

As clonal integration involves directionally opposed pathways (i.e. from undamaged ramets to damaged ones, or the reverse), clonal integration is involved either in buffering biomass loss (tolerance to herbivory) or in the transport of induced defense compounds (avoidance of herbivory), the relative role of each remains to be investigated. Clonal integration can itself be damaged by herbivory e.g. through the consumption of connections or their destruction by trampling (Charpentier et al., 1998), thereby impeding its possible involvement in the response of clonal fragments to herbivory.

\section{Effects of clonal properties on the behavior of herbivores}

By modifying the biochemical or biomechanical properties of plant tissues, induced defenses have been shown to reduce caterpillar preference for undamaged ramets of $T$. repens (Gómez and Stuefer, 2006; Gómez et al., 2008), diverting herbivores to other plant parts or species (Fig. 3). However, such responses by clonal fragments are unlikely to modify the feeding behavior of larger animals such as sheep or cattle, which are selective at larger spatial scales (WallisDeVries et al., 1999). Contrasting clonal architectures affect ramet spatial distribution and determine their vicinity, subsequently modifying associational resistance patterns. For instance, guerilla species are likely to favor associational resistance and divert herbivores to more palatable ramets, as they increase the probability of intra- or inter-specific contacts (Fig. 2). By contrast, ramet aggregation caused by the phalanx strategy generates a concentration of feeding resources that has contrasting effects on herbivores, depending on their foraging behavior and detection ability. On the one hand, resource concentration is more attractive to the herbivore and increases the probability of a particular ramet being damaged. On the other hand, 
it may reduce this probability by dilution effects. Thus, as herbivory affects clonal architecture (see above), it is hypothesized in turn to modify further patterns of damage caused to clonal plants. Finally, connections, especially stolons, may act as corridors for small herbivores, thereby favoring their displacements among ramets (Stuefer et al., 2004) (Fig. 3). Investigating the responses of herbivores, especially invertebrate herbivores, which are the most likely to perceive spatial heterogeneity and distribution of ramets at the clonal fragment scale, is a promising field of research.

\section{Plant-pollinator interactions}

\section{Theory}

Pollination corresponds to pollen transfer from male to female flower parts. It occurs within a flower or between two flowers. Animal pollination is a mutualistic, rarely obligate, interaction in which a plant provides resources to an animal, most often an insect, acting as a pollen vector (the pollinator; Box 1; Kearns et al., 1998). Floral traits (e.g., flower shape and size, Lázaro et al., 2013), nectar rewards (e.g., Real, 1981; Ott et al., 1985), as well as the density, abundance, and spatial arrangement of flowers influence pollinator foraging behavior and flower visitation rates. Being more conspicuous, large floral displays are expected to be more attractive to pollinators (Charpentier, 2002; Harder et al., 2004) as suggested by increased flower visitation rates (Delmas et al., 2014) or pollen loads on these flowers (Brys and Jacquemyn, 2010). However, this effect varies among pollinator taxa (Thompson, 2001) and with the scale considered (from the inflorescence to the plant or plant assemblage) (e.g. Lobo et al., 2016). Moreover, pollen transfer generally follows a leptokurtic curve (Vallejo-Marín et al., 2010 and references therein; Severns et al., 2011) meaning that short distances between flowers increase the probability of pollen dispersal (Brys and Jacquemyn, 2010). Foraging distances are likely to be rather short, because of the limited range of detection of pollinators. For instance, due to their angle of detection and flying height, the bumblebee Bombus terrestris (L.) can only distinguish the color of flower at a distance of less than $35 \mathrm{~cm}$ (Keasar, 2000). Consequently, even in the case of less attractive species, flower clumping is likely to "trap" pollinators (Hanoteaux et al., 2013) i.e., once a patch is entered, pollinators are more likely to forage on neighboring flowers in the same patch than to leave the patch to visit to another more distant one. Intraspecific flower aggregation is thus favorable as it increases visitation rates, while limiting pollinator availability for other plant species (Hanoteaux et al., 2013). However, increasing patch size is often correlated with increasing visitation frequency and also with a decreasing proportion of flowers visited inside the patch (Ishihama and Washitani, 2007). 
Moreover, as foraging distance varies among pollinators, and is generally correlated with body size, the spatial scale of pollinator response to flower aggregation is more variable than generally assumed (DiLeo et al., 2018). Apart from the spatial arrangement of flowers, pollinators also respond to floral traits and temporal or spatial variations in nectar abundance. Large bees were observed to visit flowers only at the daily peaks of nectar quantity (Real, 1981), while spatial variations in nectar rewards can modify pollinators' flying distances (e.g., Ott et al., 1985 with Bombus pensylvanicus). Pollinator specialization can also blur the effect of the spatial arrangement of flowers on foraging behavior. Flowers that produce the largest quantity and highest concentration of nectar are generally visited more frequently (Heinrich, 1975), but pollinators may also specialize in a few plants, although this behavior differs between the pollinator species and functional or life history traits (e.g., tongue length, social behavior, foraging period, lifespan, etc.) and can also vary at the individual level (Heinrich, 1975).

The effects of spatial arrangements of flowers on pollination vary with the density and size of the plant population. On the one hand, the magnetic effect of a highly conspicuous species is likely to change with its density and spatial arrangement, benefiting heterospecific neighbors with low abundances and shifting to a competitive effect when abundance is high and the spatial pattern is aggregated, at least for other rather conspicuous neighbors (Seifan et al., 2014). On the other hand, less attractive species would benefit from flower aggregation at high abundances, and from intermingling their flowers with those of more attractive species at lower abundances (Hanoteaux et al., 2013). Additionally, the effect of flower density within a patch on visitation rates and residence time is linked to population area or patch abundance (Biernaskie and Gegear, 2007; Dauber et al., 2010). The community context is particularly important across the floral traits and abundance of species when the pollinator-to-flower ratio is high, implying more competition between pollinators which then reduces their ability to choose their preferred species (Lázaro et al., 2013). At high pollinator densities, nectar resources are rapidly depleted, especially in nectar-rich flowers, leading pollinators to forage other species even if they are less rewarding (Heinrich, 1975).

Here, we question how clonal growth affects interactions between plants and their pollinators. As they govern the spatial pattern of ramets, clonal architectures would be expected to strongly interact with pollen transfer among flowers, regardless of the pollen vector (Charpentier 2002, Vallejo-Marín et al., 2010). While clonal traits very likely influence pollinator behavior, the response of clonal traits to pollinators is less clear and requires further investigation. 


\section{Potential effects of clonal properties on pollinators}

Sexual reproduction is required for the establishment of a new genet and seed production remains a significant life-history trait in clonal plants (Eriksson, 1992; 1997). The existence of trade-offs between clonal growth and sexual reproduction has been seriously called into question. These trade-offs may be direct when the production of clonal or reproductive structures are mutually exclusive, or indirect through resource limitation (Vallejo-Marín et al., 2010; Herben et al. 2015). Conversely, clonality can enable the production of large sets of flowering ramets, thereby increasing the floral display at the genet level, at least for polycarpic species with indeterminate growth (Vallejo-Marín et al., 2010) (Fig. 3). Consequently, clonality and clonal architecture likely influence pollinator foraging behavior. Large floral displays generated by genet clonal expansion as well as ramet aggregation linked with the phalanx strategy should attract pollinators. Large patches of flowering ramets have been shown to increase the frequency of visits by pollinators in the clonal self-incompatible Primula sieboldii (Ishihama and Washitani, 2007) as well as in the clonal shrub Jasminum fruticans (Thompson, 2001), supporting the expected positive effect of patch size on attractiveness. However, neither study provided clear evidence for the role of clonal growth in these patterns (in the former study, patch size was experimentally manipulated, while in the latter, the authors did not check if a patch was only the result of clonal expansion). Several studies on selfing (i.e., pollen transfer within a single plant) and especially geitonogamy (i.e., pollination between different flowers of a single individual) patterns in clonal plants demonstrated that pollen transfers occur to a large extent between the ramets of a single genet (Eckert, 2000; Albert et al., 2008). This pattern is in accordance with observed movements of pollinators on flowers of the clonal shrub Vaccinium myrtillus, most of which (89\%) occurred at distances of less than $40 \mathrm{~cm}$ (Albert et al., 2008). By contrast, the expectation that flower aggregation caused by clonal growth leads to similar effects on pollinator behavior to those encountered in non-clonal plants has also been questioned experimentally. Liao and Harder (2014) suggested that flower aggregation caused by clonal growth (i.e., inter-ramet flower aggregation) results in fewer visitations than when flowers are aggregated in a single inflorescence or between inflorescences of single ramets. Accordingly, $82 \%$ of about 2,000 movements of the bumblebee Bombus ignitus among flowers of the clonal herb Aconitum kusnezoffii occurred between flowers on single ramets, and the remaining $18 \%$ occurred between different ramets of a clonal fragment (Hu et al., 2015). These results are mainly explained by the preferentially vertical, mainly upward (Liao and Harder, 2014), foraging behavior of pollinators over horizontal displacements. To our knowledge, evidence for the effect of increased flower aggregation or patch size linked with clonal 
expansion and clonal architecture on pollinator behavior is still lacking. Such potential effects of clonal architecture are likely to depend on several factors, in particular patch size, the distance between patches or pollinator foraging distance (Hanoteaux et al., 2013). For the trapping effect to function, the size of the aggregate must be at least as large as the flower detection range of pollinators. For instance, in the distylous rhizomatous herb Menyanthes trifoliata, van Rossum et al. (2015) recorded between-morph (i.e. long vs. short-styled) pollination despite the spatial aggregation of morphs resulting from genet clumping (phalanx architecture), since inter-morph distances were shorter than the flying capacity of the pollinators. The expected trapping effect associated with phalanx architecture may be detrimental to pollinators if the quality of the patch they enter is low. Accordingly, artificial non-rewarding flowers were more frequently visited by bumblebees when they were arranged in clumps than when they were intermingled with rewarding flowers (Keasar, 2002). In the mass-flowering non-clonal tree Tabebuia aurea, large floral displays at the inflorescence level are highly attractive. Yet, inflorescences are composed of flowers at different stages of development, with about $37 \%$ of them distributing no nectar and $65 \%$ less than $1 \mu \mathrm{L}$ of nectar (Lobo et al., 2016). Similarly, due to phenological properties and more precisely, to the timing and synchronization of ramet flowering, phalanx architecture could result in an aggregation of ramets of contrasting values for pollinators. Although often overlooked, the temporal variations in resource display linked to plant species turnover strongly orients pollinators towards different species (Petanidou et al., 2008). The lifespans of ramets and clonal fragments are generally uncorrelated, as the clonal fragment lives longer than its component ramets (see section on plant-plant interactions). If ramet phenology and, more specifically, flowering is not synchronized among ramets, clonality would allow the clonal fragment to maintain a longlasting floral display for pollinators, favorable to both the clonal plant and its pollinators due to a longer flowering period than that of non-clonal plants.

Consequently, the response of pollinators to plant clonal properties appears to be an exciting area for investigation involving multiple questions, among which (1) whether and to what extent does flower aggregation generated by clonal growth differ from non-clonal aggregation, and what are its effects on both pollinator behavior and consequences for the plant; (2) whether the spatial and temporal scales of ramet flowering match those of pollinator foraging behavior.

\section{Consequences of clonality and pollinator service for sexual reproduction in clonal plants}


Although not universal and often modulated by other factors (see above), ramet aggregation caused by phalanx architecture can positively influence interactions with pollinators. However, this may not benefit the plant (Table 2). The phalanx strategy not only results in the concentration of floral resources but also in the aggregation of flowering ramets that belong to the same clonal individual (Fig. 2). Consequently, either by being more attractive or by trapping pollinators inside a clump of genetically identical ramets, phalanx architecture increases the risk of geitonogamy (Charpentier, 2002). As it reduces outcrossing rates, geitonogamy may reduce fitness due to inbreeding depression (Vallejo-Marín et al., 2010). The effect of geitonogamy is even more severe in self-incompatible species, in which seed production is closely linked to the presence of compatible mates in the vicinity (Wang et al., 2005; Scobie and Wilcock, 2009) and benefits from high clonal diversity (Aigner, 2004). Pollen discounting and reduced seed set in response to the scarcity of compatible mates has been reported in several self-incompatible and animal-pollinated clonal species e.g. the rhizomatous herbs Calystegia collina (Wolf and Harrison, 2001) and Dithyrea maritima (Aigner, 2004), the rhizomatous macrophyte Nymphoides peltata (Wang et al., 2005) and the stoloniferous dwarf shrub Linnaea borealis (Scobie and Wilcock, 2009). Accordingly, depending on pollinator abundance and behavior, clonal growth may strongly interfere with and modify self-incompatibility mating systems, and even lead to plant sterility (Barrett, 2015). In heteromorphic systems, where the number of compatible mates is very low, the interaction between clonal growth and limited pollen dispersal, caused for instance by short pollinator foraging distances, can even disrupt mating systems leading to the evolution of self-fertilization (Barrett and Forno, 1982; Leme da Cunha et al., 2014; Barrett, 2015). A simulation study on homomorphic systems demonstrated that the loss of compatible mates (associated with low S-allele richness) and limited probability of pollination (associated for instance with pollinator abundance or behavior) have greater joint effects than simple additive ones on plant reproductive performance and population viability, especially at intermediate pollination frequencies (Young et al., 2012). As extensive clonal growth is likely to affect genetic diversity at the community level (e.g. Vallejo-Marín et al., 2010), it could be expected to incur such negative effects on sexual reproduction and seed set.

Thus, one condition for clonal growth to favor outcrossing is encountered in large monospecific but genetically diverse patches, like those generated by guerilla architecture (Charpentier, 2002). For instance, in Kincaid's lupine Lupinus oreganus, a rhizomatous Fabaceae that produces large genets with sparsely intermixed ramets (guerilla architecture), the bumblebees Bombus spp. have ca. $85 \%$ of chance of successively visiting ramets of two different genets (Severns et al., 2011). In more diverse plant communities (Fig. 2), guerilla 
architecture probably increases species switches, thereby wasting pollen. The risk of geitonogamy and the success of sexual reproduction in clonal plants depends on the behavior, mobility and flower detection capacities of pollinators (Table 2). Long-distance foraging pollinators increase outcrossing rates even in clumped genets (van Rossum et al., 2015), thereby supporting efficient sexual reproduction and genetic diversity of clonal plants. Conversely, by enhancing intra-genet pollen transfer, short-distance foraging pollinators may be particularly detrimental to sexual reproduction in phalanx species. Consequently, phalanx plants are more likely to benefit from pollination by rather mobile species. In addition, pollinator foraging behavior can limit the risk of geitonogamy even between clumped ramets, for instance by preferentially vertical rather than horizontal movements (Liao and Harder, 2014), or by visiting a very limited number of ramets during a bout (Wilson et al., 2005). To our knowledge, evidence for the expected relationships between pollinators and clonal traits, as well as their potential consequences for the relative abundance of either strategy (i.e. phalanx vs. guerilla) or of clonal plants compared to non-clonal ones in plant assemblages is still lacking.

\section{Plant-fungi interactions}

\section{Theory}

Plants are associated with complex and diverse microbiota including bacteria, archaea and fungi (Bulgarelli et al., 2012; Lundberg et al., 2012; Bulgarelli et al., 2013; Lê Van et al., 2017). These microorganisms develop inside or at the surface of any plant structure: shoots, leaves, roots, and seeds. The present review only focuses on the fungal compartment of this microbiota, which is the best documented. Interactions between plants and fungi involve relationships that range from mutualistic to parasitic. In mutualists, the symbiotic arbuscular mycorrhizal fungi (AMF) are fully dependent on the plant for carbohydrates, in return providing nutrients such as phosphorus or zinc (Vandenkoornhuyse et al., 2015). Fungi are particularly important for plant nutrition and growth (Hodge et al., 2009; Vannier et al., 2015) and may also be involved in nonnutritional ecological functions such as the alleviation of abiotic stresses including drought, heat or waterlogging, and resistance to pathogens or herbivory (Smith and Read, 2008; Vandenkoornhuyse et al., 2015; Vannier et al., 2015). Conversely, some fungi isolates are parasitic. Such parasitic behavior includes apparently mutualist species that are in fact bad AMF cooperators for the plants, i.e. provide fewer nutrients than they should (Johnson et al., 1997; Saikkonnen et al., 1998), and pathogens that develop on the host, potentially causing disease and possibly death. 
The intensity of colonization by microorganisms and especially by symbionts varies among plant hosts: for instance, AM fungal colonization can vary from 0 to $90 \%$ depending on the plant species and the developmental stage (Smith and Read, 2008). The composition of fungal assemblages primarily depends on local environmental constraints, i.e. where microorganisms are recruited by the plants (e.g. Schlaeppi et al., 2014). However, the host identity (e.g. Vandenkoornhuyse et al., 2002; Ofek-Lalzar et al., 2014), and to a lesser extent, its genotype and phenological status (Manter et al., 2010; Lundberg et al., 2012; Bulgarelli et al., 2012), have been shown to be stronger drivers than previously thought (Martinez-Garcia and Pugnaire 2011; Yang et al. 2012). Fungal mutualist communities differ significantly between host-plant species, even when these plant species co-occur in natura (Vandenkoornhuyse et al., 2002; 2003). The host-preference effect was interpreted as the consequence of plant filtering, in particular through a carbon reward process to the best cooperators (i.e., providing the largest quantities of phosphorus to the host plant in exchange for carbon) (Kiers et al., 2011; Duhamel and Vandenkoornhuyse, 2013). This preferential association with a particular host has also been demonstrated in plant pathogens (Harlan, 1976). Because of their positive or negative effects on their host plants, fungi have a deep impact on the establishment, growth and survival of plant species, thereby determining both their coexistence and ecosystem productivity (van der Heijden et al., 1998; 2008).

Compared to non-clonal plants, clonality may represent a way to escape, or the reverse, to facilitate fungal colonization and expansion (Tables 1,2). The number of potential habitats for fungi indeed results from the investment in plant clonal multiplication whereas their distribution is driven by plant lateral expansion, i.e. branching intensity and internode length. Fungal transmission from one plant to another is also facilitated by contacts among plants (between roots or leaves) or hyphal growth, and hence should be determined by the spatial arrangement of the ramets and clonal integration, and their transmission between plant organs.

\section{Changes in the allocation to clonal multiplication in response to fungi}

Clonal plants can reproduce both by seed through sexual reproduction and by clonal multiplication. The life-history trade-off between these two modes of reproduction may influence their ability to escape parasitic species or to facilitate colonization and expansion of mutualists (Tables 1,2). High investment in ramet production at the expense of seed production increases the availability of local microhabitats for fungi and hence favors the spread of mutualists. Evidence of the effect of fungi on a life-history trade-off between sexual reproduction and clonal multiplication is reported in Streitwolf-Engel et al. (2001). AM fungal 
species can manipulate the clonal multiplication of Prunella vulgaris and produce, for instance, up to a 1.8-fold change in the number of ramets depending on the fungal isolate concerned (Streitwolf-Engel et al., 1997). However, plant responses vary depending on the composition of the fungi assemblages inoculated. Stachys sylvatica showed both enhanced flower production or a higher number of connections per plant and fewer flowers, depending on the inoculation treatment (de la Pena and Bonte, 2011).

In contrast, in response to pathogens, seed production rather than clonal propagation helps avoid diseases over time, as most pathogens cannot be vertically transmitted through seeds. This response would then be expected to involve enhanced sexual reproduction with faster and more intensive seed and flower production, together with a faster developmental switch from vegetative to flowering ramets. However, this is not a generalized response pattern. According to published experiments, colonization of Lolium perenne individuals by the fungal endophyte Neotyphodium lolii stimulates ramet production but has no effect on the proportion of flowering ramets (Cheplick, 2008). In addition, in natura, responses are contrasted with either a higher number of potentially flowering ramets (Clay, 1990) or no long-term enhancement of reproduction (Faeth and Hamilton, 2006, Neotyphodium sp. on Festuca arizonica; Olejniczak and Lembicz, 2007, Epichloe typhina on Puccinella distans).

\section{Response of clonal properties to associations with fungi}

Clonal plants would be expected to modify their network architecture in response to negative or positive interactions with fungi, to respectively limit (Koubek and Herben, 2008) or support their dispersal between connected ramets (Vannier et al., 2018) (Tables 1, 2). This response depends to a great extent on the host plant genotype (Streitwolf-Engel et al., 2001; Hesse et al., 2004).

On the one hand, mutualistic interactions with fungal endophytes are expected to slow down clonal growth so it corresponds to the slow speed of hyphal growth; and to delay fragmentation to favor endophyte transmission to daughter ramets. Additionally, integration between ramets should promote the spread of microorganisms through the connections that then represent preferential pathways (see following section). In a pioneer study, Streitwolf-Engel et al. (1997) demonstrated that AM fungal inoculation modified stolon length and branching intensity in two stoloniferous species, Prunella vulgaris and P. grandiflora (Lamiaceae). Stolons vary from two to three fold in length and up to two fold in branching intensity depending on the AM fungal isolate. The effect of AM fungi on plant traits differed between the two plant species despite their phylogenetic proximity. Similar marked differences in plant responses 
were found in five stoloniferous co-occurring plant species (Sudová, 2009). Manipulation of plant clonal traits by fungal isolates has been demonstrated but so far, without extending and interpreting these responses as a plant adaptive strategy linked to the presence of mutualists. Moreover, thanks to their beneficial role in plant nutrition, AM fungal symbioses may replace the benefit of clonal integration on plant growth, especially in low-nutrient habitats. Consequently, reduced physiological integration is selected, as first demonstrated by Du et al. (2009) in Trifolium repens. These authors used an experiment in which individual plants were grown in heterogeneous environments with inversely correlated nutrient and light availabilities. T. repens individuals displayed lower ramet specialization in presence than in absence of AM fungi. This reduction of the "division of labor" classically observed in clonal plants (Stuefer, 1998) was even more pronounced when the plant was inoculated with five isolates rather than with a single one, suggesting that higher richness in AM fungal species is more beneficial for plant nutrition, likely because of ecological complementarity. Most studies that analyzed mutualist effects on plant traits were based on AM fungal symbioses, thus calling for work on other components of the microbiota.

On the other hand, pathogens induce a large range of defense responses in clonal plants as described by Koubek and Herben (2008). The first is an increase in horizontal growth to lower the risk of infection for daughter ramets (e.g. clonal growth may be faster than the mycelium growth in fungi). Evidence for a decrease in the pathogen infection rate of daughter ramets depending on their distance from their mother was found in Lactuca sibirica in response to the foliar fungus Puccinia minussensis (Wennstrom and Ericson, 1992), in Cirsium arvense responding to the colonization of Puccinia punctiformis (Frantzen, 1994), and in the stoloniferous Trientalis europeaea responding to colonization by Urocystis trientalis (Piqueras, 1999b). Additionally, splitting the physical connection between ramets stops the pathogen spreading as demonstrated in a modelling study by Piqueras and Klimeš (1998).

\section{Clonal properties determine fungal community structure}

The non-random spatial distribution of ramets linked to clonal growth likely subsequently affects the distribution of their associated microorganisms (Fig. 3). The spatial aggregation of ramets can indeed structure the distribution of AM fungi because it promotes the transmission of the microbiota from one ramet to another within the same clonal fragment. Although they did not explicitly demonstrate such an effect on AM dispersal, Bittebiere et al. (in press) showed that the richness and equitability of the AM fungal communities associated with the phalanx Brachypodium pinnatum and the guerilla Elytrigia repens, respectively, responded at 5 and 15 
$\mathrm{cm}$ scale to the composition and abundance of plant species in the neighborhood of the host plant, i.e. relative to their differences in clonal mobility.

At the scale of one clonal plant fragment, connections between ramets, i.e. physical integration, should promote the colonization of other ramets. A role for stolons or rhizomes as corridors for microorganisms has long been suggested for pathogens (Stuefer et al., 2004) and even simulated using modelling approaches (Koubek and Herben, 2008; Sakai and Takada, 2016), although no empirical evidence has been produced for fungal pathogens so far (Fig. 3). However, in the case of mutualists, colonization of related ramets along their connecting rhizome was reported by Watson et al. (2002) in the clonal Podophyllum peltatum, despite the fact colonization was not homogeneous among ramets belonging to the same rhizome, with ramets of intermediate age being the most colonized (higher percentage of root colonization by AM fungi). More recently, using an experimental approach and mass-sequencing analyses, Vannier et al. (2018) demonstrated transmission between mother and daughter ramets of a whole microbiota including bacteria and fungi in clonal fragments of Glechoma hederacea. For fungi, spread is probably facilitated by hyphal colonization of stolon tissues (Vannier et al., 2016). This finding led to the novel idea that this transmission ensures the continuity of partnership between the clonal plant and its symbionts and limits the cost of looking for symbionts in the newly colonized patch. This, in turn, led to the extension of the existing theory linking plants to their symbionts to the specific case of clonal plants, with the emergence of the meta-holobiont concept (Vannier et al., 2019).

In addition to modifying the composition and distribution of fungal species, clonal plants select these species based on their functional strategies differently from non-clonal plants. For instance, Lopez-Garcia (2014) compared AM fungal traits in annual plants, perennial herbaceous and perennial woody species of two taxonomic groups (Fabaceae and Asteraceae) that were experimentally inoculated. Interestingly, perennial clonal vegetation (as opposed to annual plants) is associated with AM fungi preferentially dispersing through hyphal multiplication rather than through spores (Lopez-Garcia, 2014). The longer lifespan of perennial host plants may indeed facilitate fungi with low sexual reproduction. The selection of particular fungal strategies may also be indirect. For instance, through the comparison of experimentally connected and disconnected ramets of Glechoma longituba in controlled conditions, Lei et al. (2014) demonstrated that physiological integration alters carbon and nitrogen distribution within the ramet rhizosphere, determining the relative proportion of saprobic and mycorrhizal fungi in the plant microbiota. Clonal plant and AM fungi traits thus appear to be closely linked. However, too few works have tackled this topic so far, and our 
understanding of how plant clonality drives fungal community assembly is consequently still limited.

\section{Clonal traits and a new understanding of plant biotic interactions}

\section{Clonal traits in bipartite interactions}

Based on our literature review, we argue that clonal traits deeply affect all plant biotic interactions and their outcomes, thereby causing changes in plant community assembly and ecosystem functioning. Indeed, we clearly highlighted the fact that clonal traits may not only be response traits (Tables 1,2) but also effect traits (Fig. 3) for positive (facilitation, mutualism) and negative (competition, herbivory, parasitism, pathogens) interactions involving plants, although much remains to be investigated. Even though in this review, we only focus on direct interactions with living plants, we also expect clonal traits to affect indirect interactions. In particular, changes in plant traits induced by interactions with other plants or organisms should still have consequences after the death of the plant. As clonality drives plant resources acquisition and management (D’Hertefeld and Jónsdóttir, 1994; Price and Marshall, 1999; Alpert and Stuefer, 1997), it determines the quantity and quality of litter produced after plant tissue senescence (Cornelissen et al., 2014), and therefore has indirect effects on plant regeneration (Grubb, 1977; Derner and Briske, 1999) or on decomposer community assemblages (Barbe et al., 2017). Further work including these indirect biotic interactions based on the 'afterlife' consequences of variations in clonal traits should advance our understanding of the role of clonality in ecosystem functioning.

Plants face environmental heterogeneity that may even be reinforced by their biotic interactions. Throughout our review, we identified convergent responses of clonal traits that help the plant cope with environmental heterogeneity. First, we gathered literature reporting that clonal plants adjust their architecture to adaptively position their ramets away from negative interactions (especially competition, locally depriving resources) (de Kroon and Hutchings, 1995; Oborny and Cain, 1997; Herben and Novoplansky, 2010). This foraging behavior is mostly due to variations in internode length (Sutherland and Stillman, 1988; Price and Hutchings, 1996) or in branching frequency (Cain, 1994; Oborny and Cain, 1997) (for more details, see the section on plant-plant interactions). Based on these elements, we hypothesize that the foraging of clonal plants also occurs in response to other interactions, for instance to buffer the heterogeneous distribution of mutualists like AM fungi. Preliminary evidence for this response has been reported by Vannier et al. (2016), but this hypothesis remains to be 
thoroughly tested. Second, we highlighted the fact that physical and physiological integrations buffer environmental heterogeneity induced by varying biotic interactions (see Tables 1, 2) while resource storage supports tolerance responses to negative interactions (e.g., Beaulieu et al., 1996; Cheplick, 1997; Cheplick and Gutierrez, 2000). More specifically, integration allows the plant to average biotic interaction effects over the entire clonal fragment by providing nutrients or photoassimilates (e.g., Price and Hutchings, 1992; D’Hertefeld and Jónsdóttir, 1994; Gough et al., 2002), defense molecules (e.g., Gómez and Stuefer, 2006), and even by transferring symbiotic species through the clonal network (Vannier et al., 2018).

Our literature review further revealed that most clonal trait responses to biotic interactions strongly depend on the clonal structure considered (ramet, clonal fragment, or genet). Yet, the attention paid to this issue has varied with the biotic interaction considered. For instance, the discrepancy between spatial scales of response (e.g. ramet vs. clonal fragment) is rarely taken into consideration in studies of plant-microorganism interactions, with the exception of a few papers focused on ramet specialization (Du et al., 2009; Vannier et al., 2016), whereas trait responses and biomass allocation patterns have been the subject of deeper investigations of plant-herbivore interactions (see e.g. Li et al., 2004; Mohammad Esmaeili et al., 2009). Differences in plant responses may be related to the scales at which the two interacting organisms (i.e. the plant, and another plant, a microorganism, or an animal) actually perceive the interaction. The scale of the detected environmental heterogeneity is related to the clonal structure (clonal fragment vs. ramet), and the size of the clonal fragment (Oborny and Cain, 1997; Alpert and Simms, 2002). Moreover, responses at the ramet level have either no likelihood or high likelihood of being perceived by large herbivores or by small low-dispersal organisms such as AM fungi or other plants. Plastic adjustments in response to herbivory require a match between the spatio-temporal scale of clonal propagation and herbivore or pathogen dispersal (Stuefer et al., 2004). In addition, we noticed that the time scale of clonal plant interactions is usually absent in the existing literature except in studies of competition (see e.g. Bittebiere and Mony, 2015) or in response to herbivory (e.g. Gómez et al., 2010). As interactions may last beyond the lifespan of the ramet, we strongly recommend including the time dimension in future studies of plant biotic interactions.

Clonal plants thus display very different phenotypes in response to the different biotic interactions which may subsequently have wide implications for their effect on other interactions. Additionally, as clonal traits determine the spatial patterns of plant species and respond to this self-generated heterogeneity, they are likely to generate feedback loops in plant biotic interactions. This underlines the importance of not only between but also within species 
variations in clonal traits for functional ecology and calls for considering interactions at higher levels of complexity i.e. simultaneously involving two or more interactions.

\section{Clonal traits in multitrophic level interactions}

In our review, we highlight the importance of clonal traits in biotic interactions involving plants. However, we considered all these interactions - with other plants, animals, and microorganisms - independently (i.e. bipartite interactions), even though ecosystems encompass complex networks of interactions in which plants are a central compartment (van der Putten et al., 2010).

Within complex interaction networks, the observed phenotype of clonal plants may result from several interactions. The response to a particular interaction can indeed be mediated by another interaction. For instance, clonal traits are known to support plant response to herbivory by promoting the translocation of defense signaling substances within the entire clonal fragment (for more details, see section on herbivory, Gómez and Stuefer, 2006; Gómez et al. 2008; Chen et al., 2011). In parallel, these substances activate AM fungi recruitment to contribute to setting up plant defense mechanisms against herbivores (Mei and Flinn, 2010) (Fig. 4a). Conversely, clonal traits may simultaneously affect different interacting biological compartments: the effects of a clonal trait on a particular interaction determine its effects on another interaction. As shown in the section on plant-plant interactions, clonal traits play a significant role in plant competition and hence drive the spatial distribution of plant resource acquiring organs i.e. the availability of flowers for pollinators, or of roots for AM fungi (Fig. 4b). These clonal trait feedbacks on their own effect and response to plant interactions, can obviously occur at every node of complex interaction networks.

Yet, we observed that the literature investigating the role of plant traits in multitrophic level interactions remains scarce and does not explicitly include clonal traits. First, Blomqvist et al. (2000) tested the effect of fine-scale plant distribution, probably relying on species clonal propagation, on interactions with above-ground vertebrates and below-ground pathogenic invertebrates. In their paper, in which the different mechanisms (phyto-parasitism with nematodes, facilitation with ants, competition between plants) were studied separately using an experimental approach, the rhizomatous Carex arenaria adjusted its foraging behavior according to ant activity (ramets were more aggregated in ant hills due to ant beneficial effect on soil structure and nutrients), while ramet growth was hampered by soil nematodes (rhizomes were shorter in length). Second, in another study dealing with the rhizomatous species Chamerion angustifolium, the presence of AM fungi associated with plant roots led to higher 
biomass allocation to flowers than to vegetative growth, thereby impacting pollinator behavior (Wolfe et al., 2005). When inoculated, pollinator visitations and the seed set of this species were up to two times higher than in non-inoculated plants, regardless of the AM fungal isolate used (Glomus intraradices vs. Gigaspora gigantea). Conversely, arthropods had no effect on herbivory, as measured by both the abundance of herbivores on plants, and the amount of damage to leaves.

In light of this information, novel works that take clonality explicitly into account in complex interactions are necessary to solve important issues including (1) disentangling the relative effects of different interactions in clonal plant response; (2) determining the direct and indirect effects of clonality on multitrophic level interactions with possible feedback; and (3) better integrating clonal traits in the theoretical corpus on plant assembly rules to predict changes in biodiversity and ecosystem functioning.

Toward a new understanding of the role of clonality in plant community assembly and ecosystem functioning

Clonal plants, especially those that develop through a network structure, dominate the plant cover of many ecosystems (van Groenandael et al., 1990). In this review, we have demonstrated that their traits drive biotic interactions. This key role, which likely extends to complex interaction networks, is certainly one underlying mechanism of clonal plant involvement in ecosystem functioning [as reviewed by Cornelissen et al. (2014)]. We are thus of the opinion that integrating clonal traits in renewed theories on plant species coexistence and ecosystem functioning is a promising way to better forecast the fate of plant species in response to changes in biotic interactions.

\section{Acknowledgments}

The authors are grateful to T. Herben, J. Klimešovà, and R. Salguero-Gómez for the opportunity of contributing to this special issue on plant clonality. The authors also wish to thank Pr. P. Vandenkoornhuyse for his valuable comments on the manuscript. 


\section{References}

Aigner, P.A., 2004. Ecological and genetic effects on demographic processes: pollination, clonality and seed production in Dithyrea maritima. Biol. Conserv. 116, $27-34$.

Albert, T., Raspé, O., Jacquemart, A.-L., 2008. Influence of clonal growth on selfing rate in Vaccinium myrtillus L. Plant Biol. 10, 643-649.

Alpert, P., Simms, E. L., 2002. The relative advantages of plasticity and fixity in different environments: when is it good for a plant to adjust? Evol. Ecol. 16, 285-297.

Alpert, P., Stuefer, J.F., 1997. Division of labour in clonal plants, in: de Kroon, H., van Groenendael, J. (Eds.), The ecology and evolution of clonal plants. Backhuys Publishers, Leiden, pp. 137-154.

Asaeda, T., Rajapakse, L., Manatunge, J., Sahara, N., 2006. The effect of summer harvesting of Phragmites australis on growth characteristics and rhizome resource storage. Hydrobiologia $553,327-335$.

Bakker, E.S., Ritchie, M.E., Olff, H., Milchunas, D.G., Knops, J.M.H., 2006. Herbivore impact on grassland plant diversity depends on habitat productivity and herbivore size. Ecol. Lett. 9, $780-788$.

Barbe, L., Jung, V., Prinzing, A., Bittebiere, A.-K., Butenschoen, O., Mony, C., 2017. Functionally dissimilar neighbors accelerate litter decomposition in two grass species. New Phytol. 214, 1092-1102.

Barrett, S.C.H., 2015. Influences of clonality on plant sexual reproduction. Proc. Natl. Acad. Sci. $112,88595-8866$.

Barrett, S.C.H., Forno, I.W., 1982. Style morph distribution in New World distribution of Eichhornia crassipes (Mart.) Solms-Laubach (Water Hyacinth). Aquat. Bot. 13, 299-306.

Beaulieu, J., Gauthier, G., Rochefort, L., 1996. The growth response of graminoid plants to goose grazing in a High Arctic environment. J. Ecol. 84, 905-914.

Begon, M., Harper, J.L., Townsend, C.R., 1996. Ecology. Blackwell Science, Oxford.

Benot, M.-L., Bittebiere, A.-K., Ernoult, A., Clément, B., Mony, C., 2013. Fine-scale spatial patterns in grassland communities depend on species clonal dispersal ability and interactions with neighbours. J. Ecol. 101, 626-636.

Benot, M.-L., Bonis, A., Rossignol, N., Mony, C., 2011. Spatial patterns in defoliation and the expression of clonal traits in grazed meadows. Botany 89, 43-54.

Benot, M.-L., Mony, C., Puijalon, S., Mohammad-Esmaeili, M., van Alphen, J.J.M., Bouzillé, J.-B., Bonis, A., 2009. Responses of clonal architecture to experimental defoliation: a comparative study between ten grassland species. Plant Ecol. 201, 621-630. 
Bertness, M.D., Callaway, R., 1994. Positive interactions in communities. Trends Ecol. Evol. 9, 191-193.

Biernaskie, J.M., Gegear, R.J., 2007. Habitat assessment ability of bumble-bees implies frequency-dependent selection on floral rewards and display size. Proc. R. Soc. B-Biol. Sci. 274, 2595-2601.

Bittebiere, A.-K, Mony, C., Maluenda, E., Gareil, A., Dheilly, A., Coudouel S., Bahin, M., Vandenkoornhuyse, P., in press. Plant landscape as a determinant of arbuscular mycorrhizal community assembly. J. Ecol.

Bittebiere, A.-K., Clément, B., Mony, C., 2013. Clonal traits outperform foliar traits as predictors of ecosystem function in experimental mesocosms. J.Veg. Sci. 24, 1001-1009.

Bittebiere, A.-K., Garbey, M., Smaoui-Feki, M., Clément, B., Mony, C., 2014. Structural blueprint and ontogeny determine the adaptive value of the plastic response to competition in clonal plants: a modelling approach. Evol. Ecol. 28, 573-590.

Bittebiere, A.-K., Mony, C., 2015. Plant traits respond to the competitive neighbourhood at different spatial and temporal scales. Ann. Bot. 115, 117-126.

Bittebiere, A.-K., Renaud, N., Clément, B., Mony, C., 2012. Morphological response to competition for light in the clonal Trifolium repens (Fabaceae). Am. J. Bot. 99, 646-654.

Bittebiere, A.-K., Saiz, H., Mony, C., 2019. New insights from multidimensional trait space responses to competition in two clonal plant species. Funct. Ecol. 33, 297-307.

Blomqvist, M.M., Olff, H., Blaauw, M.B., Bongers, T., van der Putten, W.H., 2000. Interactions between above- and belowground biota: importance for small-scale vegetation mosaics in a grassland ecosystem. Oikos 90, 582-598.

Bonanomi, G., Incerti, G., Stinca, A., Cartenì, F., Giannino, F., Mazzoleni, S., 2014. Ring formation in clonal plants. Community Ecol. 15, 77-86.

Bråthen, K.A., Agrell, J., Berteaux, D., Jónsdóttir, I.S., 2004. Intraclonal variation in defence substances and palatability: a study on Carex and lemmings. Oikos 105, 461-470.

Bråthen, K.A., Junttila, O., 2006. Infertile times: response to damage in genets of the clonal sedge Carex bigelowii. Plant Ecol. 187, 83-95.

Briske, D.D., 1996. Strategies of plant survival in grazed systems: a functional interpretation, in: Hodgson, J.,Illius, A.W. (Eds.) The Ecology and management of grazing systems. CAB International, Wallingford, pp 33-67.

Brown, N.F., Wickham, M.E., Coombes, B.K., Finlay B.B., 2006. Crossing the line: slection and evolution of virulence traits. Plos path. 2, e42. 
Bruno, J.F., Stachowicz, J.J., Bertness, M.D., 2003. Inclusion of facilitation into ecological theory. Trends Ecol. Evol. 18, 119-125.

Brys, R., Jacquemyn, H., 2010. Floral display size and spatial distribution of potential mates affect pollen deposition and female reproductive success in distylous Pulmonaria officinalis (Boraginaceae). Plant Biol. 12, 597-603.

Bulgarelli, D., Root, M., Schlaeppi, K., Ver Loren van Themaat, E., Ahmadinejad, N., Assenza, F., Rauf, P., Huettel, B., Reinhardt, R., Schmelzer, E., Peplies, J., Gloeckner, F.O., Amann, R., Eickhorst, T., Schulze-Lefert, P., 2012. Revealing structure and assembly cues for Arabidopsis root-inhabiting bacterial microbiota. Nature 488, 91-95.

Bulgarelli, D., Schlaeppi, K., Spaepen, S., Ver Loren van Themaat, E., Schulza-Lefert, P., 2013. Structure and Functions of the bacterial microbiota of plants. Ann. Rev. Plant Biol. 64, 807838.

Cain, M.L., 1994. Consequences of foraging in clonal plant species. Ecology 75, 933-944.

Callaghan, T.V., Carlsson, B. Á., Jónsdóttir, I. S., Svensson, B., Jonasson, S., 1992. Clonal plants and environmental change: introduction to the proceedings and summary. Oikos 63, 341347.

Callaway, R., Pennings, S.C., Richards, C., 2003. Phenotypic plasticity and interactions among plants: Trait plasticity and community dynamics. Ecology 84, 1115-1128.

Callaway, R.M., Kikvidze, Z., Kikodze, D., 2000. Facilitation by unpalatable weeds may conserve plant diversity in overgrazed meadows in the Caucasus Mountains. Oikos 89, 275282.

Carlsson, B. Á., Callaghan, T.V., 1990. Programmed tiller differentiation, intraclonal density regulation and nutrient dynamics in Carex bigelowii. Oikos 58, 219-230.

Castagneyrol, B., Giffard, B., Pere, C., Jactel, H., 2013. Plant apparency, an overlooked driver of associational resistance to insect herbivory. J. Ecol. 101, 418-429.

Castagneyrol, B., Jactel, H., Vacher, C., Brockerhoff, E.G., Koricheva, J., 2014. Effects of plant phylogenetic diversity on herbivory depend on herbivore specialization. J. Appl. Ecol. 51, 134141.

Castagneyrol, B., Lagache, L., Giffard, B., Kremer, A., Jactel, H., 2012. Genetic Diversity Increases Insect Herbivory on Oak Saplings. PLoS One 7, e44247.

Charpentier, A., 2002. Consequences of clonal growth for plant mating. Evol. Ecol. 15, 521530.

Charpentier, A., Mesléard, F., Thompson, J.D., 1998. The effects of rhizome severing on the clonal growth and clonal architecture of Scirpus maritimus. Oikos 83, 107-116. 
Chen, J.-S., Lei, N.-F., Liu, Q., 2011. Defense signaling among interconnected ramets of a rhizomatous clonal plant, induced by jasmonic-acid application. Acta Oecol.-Int. J. Ecol. 37, $355-360$.

Cheplick, G., 1997. Responses to severe competitive stress in a clonal plant: differences between genotypes. Oikos 79, 581-591.

Cheplick, G.P., 2008. Host genotype overrides fungal endophyte infection in influencing tiller and spike production of Lolium perenne (Poaceae) in a common garden experiment. Am. J. bot. 95, 1063-1071.

Cheplick, G.P., Gutierrez, C.M., 2000. Clonal growth and storage in relation to competition in genets of the rhizomatous perennial Amphibromus scabrivalvis. Can. J. Bot. 78, 537-546.

Chesson, P., 2000. Mechanisms of maintenance of species diversity. Annu. Rev. Ecol. Syst. 31, 343-366.

Clay, K., 1990. Comparative demography of three graminoids infected by systemic, clavicipitaceous fungi. Ecology 71, 558-570.

Cornacchia, L., van de Koppel, J., van der Wal, D., Wharton, G., Puijalon, S., Bouma, T.J., 2018. Landscapes of facilitation: how self-organized patchiness of aquatic macrophytes promotes diversity in streams. Ecology 99, 832-847.

Cornelissen, J.H.C., Song, Y.-B., Yu, F.-H., Dong, M., 2014. Plant traits and ecosystem effects of clonality: a new research agenda. Ann. Bot. 114, 369-376.

D’Hertefeldt, T., Jónsdóttir, I.S., 1994. Effects of resource availability on integration and clonal growth in Maianthemum bifolium. Folia Geobot. 29, 167-179.

Dalgleish, H.J., Hartnett, D.C., 2009. The effects of fire frequency and grazing on tallgrass prairie productivity and plant composition are mediated through bud bank demography. Plant Ecol. 201, 411-420.

Dauber, J., Biesmeijer, J.C., Gabriel, D., Kunin, W.E., Lamborn, E., Meyer, B., Nielsen, A., Potts, S.G., Roberts, S.P.M., Sõber, V., Settele, J., Steffan- Dewenter, I., Stout, J.C., Teder, T., Tscheulin, T., Vivarelli, D., Petanidou, T., 2010. Effects of patch size and density on flower visitation and seed set of wild plants: a pan-European approach. Journal of Ecology 98, 188196.

de Kroon, H., Hara, T., Kwant, R., 1992. Size hierarchies of shoots and clones in clonal herb monocultures: do clonal and non-clonal plants compete differently? Oikos 63, 410-419.

de Kroon, H., Hutchings, M.J., 1995. Morphological plasticity in clonal plants: the foraging concept reconsidered. J. Ecol. 83, 143-152. 
De la Pena, E., Bonte, D., 2011. Soil biota effects on clonal growth and flowering in the forest herb Stachys sylvatica. Acta Oecol. 37, 110-116.

Delmas, C.E.L., Escaravage, N., Pornon, A., 2014. Massive floral display affects insect visits but not pollinator-mediated pollen transfer in Rhododendron ferrugineum. Plant Biol. 16, 234243.

DeMalach, N., Zaady, E., Weiner, J., Kadmon, R., 2016. Size asymmetry of resource competition and the structure of plant communities. J. Ecol. 104, 899-910.

Derner, J.D., Briske, D.D., 1999. Intraclonal regulation in a perennial caespitose grass: a field evaluation of above- and below-ground resource availability. J. Ecol. 87, 737-747.

Derner, J.D., Briske, D.D., 2001. Below-ground carbon and nitrogen accumulation in perennial grasses: A comparison of caespitose and rhizomatous growth forms. Plant Soil 237, 117-127.

Dicke, M., Agrawal, A.A., Bruin, J., 2003. Plants talk, but are they deaf? Trends Plant Sci. 9, 403-405.

DiLeo, M.F., Holderegger, R., Wagner, H.H., 2018. Contemporary pollen flow as a multiscale process: Evidence from the insect-pollinated herb, Pulsatilla vulgaris. J. Ecol. 106, 2242-2255. Dolch, R., Tscharntke, T., 2000. Defoliation of alders (Alnus glutinosa) affects herbivory by leaf beetles on undamaged neighbours. Oecologia 125, 504- 511.

Dong, B.-C., Fu, T., Luo, F.-L., Yu, F.-H., 2017. Herbivory-induced maternal effects on growth and defense traits in the clonal species Alternanthera philoxeroides. Sci. Total Environ. 605, $114-123$.

Du, J., Yu, F.-H., Alpert, P., Dong, M., 2009. Arbuscular mycorrhizal fungi reduce effects of physiological integration in Trifolium repens. Ann. Bot. 104, 335-343.

Duhamel, M., Vandenkoornhuyse, P., 2013. Sustainable agriculture: possible trajectories from mutualistic symbiosis and plant neodomestication. Trends in Plant Sci. 18, 597-600.

Eckert, C.G., 2000. Contributions of autogamy and geitonogamy to self-fertilization in a massflowering, clonal plant. Ecology 81, 532-542.

Eckert, C.G., Barrett, S.C.H., 1993. Clonal reproduction and pattern of genotypic diversity in Decodon verticillatus. Am. J. Bot. 80, 1175-1182.

Eriksson, O., 1992. Evolution of seed dispersal and recruitment in clonal plants. Oikos 63, 439448.

Eriksson, O., 1997. Clonal life histories and the evolution of seed recruitment, in: de Kroon, H., van Groenendael, J. (Eds.), The ecology and evolution of clonal plants. Backhuys Publishers, Leiden, pp. 211-226. 
Eriksson, O., Jerling, L., 1990. Hierarchical selection and risk spreading in clonal plants, in: van Groenendael, J., de Kroon, H. (Eds), Clonal growth in plants: regulation and function. SPB Academic Publishing, The Hague, pp. 79-94.

Faeth, S.H., Hamilton, C.E., 2006. Does an asexual endophyte symbiont alter life stage and long-term survival in a perennial host grass. Microb. Ecol. 52, 748-755.

Fischer, M., van Kleunen, M., 2002. On the evolution of clonal plant life histories. Evol. Ecol. 15, 565-582.

Frantzen, J., 1994. An epidemiological study of Puccinia punctiformis (Str.) Röhl as a steppingstone to the biological control of Cirsium arvense (L.) Scop., New phytol. 127, 147-154.

Gao, Y., Wang, D., Xing, F., Liu, J., Wang, L., 2014. Combined effects of resource heterogeneity and simulated herbivory on plasticity of clonal integration in a rhizomatous perennial herb. Plant Biol. 16, 774-782.

Goldberg, D.E., 1987. Neighborhood competition in an old-field plant community. Ecology 68, 1211-1223.

Goldberg, D.E., 1990. Components of resource competition in plant communities, in: Grace, J.B., Tilman, D. (Eds), Perspectives on plant competition. Academic Press, New York, pp. 2749.

Gómez, S., Latzel, V., Verhulst, Y.M., Stuefer, J.F., 2007. Costs and benefits of induced resistance in a clonal plant network. Oecologia 153, 921-930.

Gómez, S., Onoda, Y., Ossipov, V., Stuefer, J.F., 2008. Systemic induced resistance: a riskspreading strategy in clonal plant networks? New Phytol. 179, 1142-1153.

Gómez, S., Stuefer, J.F., 2006. Members only: induced systemic resistance to herbivory in a clonal plant network. Oecologia 147, 461-468.

Gómez, S., van Dijk, W., Stuefer, J.F., 2010. Timing of induced resistance in a clonal plant network. Plant Biol. 12, 512-517.

Gough, L., Goldberg, D.E., Hershock, C., Pauliukonis, N., Petru, M., 2002. Investigating the community consequences of competition among clonal plants. Evol. Ecol. 15, 547-563.

Grime, J.P., 2001. Plant strategies, vegetation processes, and ecosystem properties. John Wiley \& Sons, Chichester.

Grubb, P.J., 1977. The maintenance of species-richness in plant communities: the importance of the regeneration niche. Biol. Rev. 52, 107-145.

Hanoteaux, S., Tielböerger, K., Seifan, M., 2013. Effects of spatial patterns on the pollination success of a less attractive species. Oikos 122, 867-880. 
Harder, L.D., Jordan, C.Y., Gross, W.E., Routley, M.B., 2004. Beyond floricentrism: The pollination function of inflorescences. Plant Spec. Biol. 19, 137-148.

Harlan, J. R. 1976. Diseases as a factor in plant evolution. Ann. Rev. Phytopathol. 14, 31-51.

Harper, J.L., 1977. Population biology of plants. Academic Press, New York.

Harper, J.L., White, J., 1974. The demography of plants. Annu. Rev. Ecol. Syst. 5, 419-463.

Hartnett, D.C., Bazzaz, F.A., 1985. The integration of neighbourhood effects by clonal genets in Solidago canadensis. J. Ecol. 73, 415-427.

Hay, M.J.M., Newton, P.C.D., 1996. Effect of severity of defoliation on the viability of reproductive and vegetative axillary buds of Trifolium repens L. Ann. Bot. 78, 117-123.

Heinrich, B., 1975. Energetics of pollination. Ann. Rev. Ecol. Syst. 6, 139-170.

Herben, T., 2004. Physiological integration affects growth form and competitive ability in clonal plants. Evol. Ecol. 18, 493-520.

Herben, T., During, H.J., Law, R., 2000. Spatio-temporal patterns in grassland communities, in: Dieckmann, U., Law, R., Metz, J.A.J. (Eds), The geometry of ecological interactions: simplifying spatial complexity. Cambridge University Press, Cambridge, pp. 48-64.

Herben, T., Goldberg, D.E., 2014. Community assembly by limiting similarity vs. competitive hierarchies: testing the consequences of dispersion of individual traits. J. Ecol. 102, 156-166. Herben, T., Hara, T., 1997. Competition and spatial dynamics of clonal plants, in: de Kroon, H., van Groenendael, J. (Eds.), The ecology and evolution of clonal plants. Backhuys Publishers, Leiden, pp. 331-358.

Herben, T., Krahulec, F., Hadincová, V., Pecháčková, S., 1994. Is a grassland community composed of coexisting species with low and high spatial mobility? Folia Geobot. 29, 459-468. Herben, T., Nováková, Z., Klimešová, J., 2014. Clonal growth and plant species abundance. Ann. Bot. 114, 377-388.

Herben, T., Novoplansky, A., 2008. Implications of self/non-self discrimination for spatial patterning of clonal plants. Evol. Ecol. 22, 337-350.

Herben, T., Novoplansky, A., 2010. Fight or flight: plastic behavior under self-generated heterogeneity. Evol. Ecol. 24, 1521-1536.

Herben, T., Šerá, B., and Klimešová, J., 2015. Clonal growth and sexual reproduction: tradeoffs and environmental constraints: Oikos 124, 469-476.

Herms, D., Mattson, W., 1992. The dilemma of plants - to grow or defend. Q. Rev. Biol. 67, 283-335. 
HilleRisLambers, J., Adler, P.B., Harpole, W.S., Levine, J.M., Mayfield, M.M., 2012. Rethinking community assembly through the lens of coexistence theory. Annu. Rev. Ecol. Evol. S. 43, 227-248.

Hodge, A., Berta, G., Doussan, C., Merchan, F., Crespi, M., 2009. Plant root growth, architecture and function. Plant Soil 321, 153-187.

Hu, Y., Barrett, S.C.H., Zhang, D.Y., Liao, W.J., 2015. Experimental analysis of mating patterns in a clonal plant reveals contrasting modes of self-pollination. Ecol. Evol. 5, 54235431.

Hulme, P.E., 1996. Herbivory, plant regeneration, and species coexistence. J. Ecol. 84, 609615.

Humphrey, L.D., Pyke, D.A., 1998. Demographic and growth responses of a guerrilla and a phalanx perennial grass in competitive mixtures. J. Ecol. 86, 854-865.

Huntly, N., 1991. Herbivores and the dynamics of communities and ecosystems. Annu. Rev. Ecol. Syst. 22, 477-503.

Ibanez, S., Lavorel, S., Puijalon, S., Moretti, M., 2013. Herbivory mediated by coupling between biomechanical traits of plants and grasshoppers. Funct. Ecol. 27, 479-489.

Ishihama, F., Washitani, I., 2007. Behavior of queen bumblebee pollinators on Primula sieboldii (Primulaceae) in response to different patch sizes and spacing. Plant Spec. Biol. 22, $167-174$.

Iwasa, Y., Kubo, T., 1997. Optimal size of storage for recovery after unpredictable disturbances. Evol. Ecol. 11, 41-65.

Jackson, R.B., Caldwell, M.M., 1993. The scale of nutrient heterogeneity around individual plants and its quantification with geostatistics. Ecology 74, 612-614.

Johnson, N.C., Graham, J.-H., Smith, F.A., 1997. Functioning of mycorrhizal associations along the mutualism-parasitism continuum. New phytol. 135, 575-789.

Jónsdóttir, I. S., Callaghan, T.V., 1988. Interrelationships between different tiller generations of interconnected tillers of Carex bigelowii. Oikos 52, 120-128.

Jónsdóttir, I.S., 1991. Effects of Grazing on Tiller Size and Population Dynamics in a Clonal Sedge (Carex bigelowii). Oikos 62, 177-188.

Jordano, P., Bascompte, J., Olesen, J.M., 2003. Invariant properties in coevolutionary networks of plant-animal interactions. Ecol. Lett. 6, 69-81.

Karban, R., Baldwin, I.T., Baxter, K.J., Laue, G., Felton, G.W., 2000. Communication between plants: induced resistance in wild tobacco plants following clipping of neighboring sagebrush. Oecologia 125, $66-71$ 
Karban, R., Maron, J., Felton, G.W., Ervin, G., Eichenseer, H., 2003. Herbivore damage to sagebrush induces resistance in wild tobacco: evidence for eavesdropping between plants. Oikos 100, $325-332$.

Karban, R., Myers, J.H., 1989. Induced plant responses to herbivory. Ann. Rev. Ecol. Syst. 20, $331-348$.

Kearns, C.A., Inouye, D.W., Waser, N.M., 1998. Endangered mutualisms: The conservation of plant-pollinator interactions. Annu. Rev. Ecol. Syst. 29, 83-112.

Keasar, T., 2000. The spatial distribution of nonrewarding artificial flowers affects pollinator attraction. Anim. Behav. 60, 639-646.

Keddy, P.A., 2010. Wetland Ecology. Principles and conservation, Cambridge University Press, Cambridge.

Keddy, P.A., Twolan-Strutt, L., Wisheu, I.C., 1994. Competitive effect and response rankings in 20 wetland plants: are they consistent across three environments? J. Ecol. 82, 635-643.

Kiers, E.T., Duhamel, M., Beesetty, Y., Mensah, J.A., Franken, O., Verbruggen, E., Felbaum, C.R., Kowalchuck, G.A., Hart, M.M., Bago, A., Palmer, T.M., West, S.A., Vandenkoornhyse, P., Jansa, J., Bucking, H., 2011. Reciprocal rewards stabilize cooperation in the mycorrhizal symbiosis. Science 333, 880-882.

Kleijn, D., Treier, U.A., Muller-Scharer, H., 2005. The importance of nitrogen and carbohydrate storage for plant growth of the alpine herb Veratrum album. New Phytol. 166, $565-575$.

Klimeš, L., 1999. Small- scale plant mobility in a species- rich grassland. J. Veg. Sci. 10, 209218.

Klimeš, L., Klimešová, J., Hendriks, R., van Groenendael, J., 1997. Clonal plant architecture: a comparative analysis of form and function, in: de Kroon, H., van Groenendael, J. (Eds.), The ecology and evolution of clonal plants. Backhuys Publishers, Leiden, pp. 1-29.

Klimešová, J., Klimeš, L., 2007. Bud bank and their role in vegetative regeneration - A literature review and proposal for simple classification assessment. Persp. Plant Ecol. Evol. Syst. 8, 115-129.

Kohler, F., Gillet, F., Gobat, J.M., Buttler, A., 2004. Seasonal vegetation changes in mountain pastures due to simulated effects of cattle grazing. J. Veg. Sci. 15, 143-150.

Koubek, T., Herben, T., 2008. Effect of systemic diseases on clonal integration: modelling approach. Evol. Ecol. 22, 449-460.

Kraft, N.J.B., Godoy, O., Levine, J.M., 2015. Plant functional traits and the multidimensional nature of species coexistence. Proc. Natl. Acad. Sci. 112, 797-802. 
Lavorel, S., Garnier, E., 2002. Predicting changes in community composition and ecosystem functioning from plant traits: revisiting the Holy Grail. Funct. Ecol. 16, 545-556.

Lázaro, A., Jakobsson, A., Totland, Ø., 2013. How do pollinator visitation rate and seed set relate to species' floral traits and community context? Oecologia 173, 881-893.

Lê Van, A., Quaiser, A., Duhamel, M., Michon-Coudouel, S., Dufresne, A., Vandenkoornhyuse, P., 2017. Ecophylogeney of the endospheric root fungal microbiome of cooccurring Agrostis stolonifera. PeerJ 5, e3454.

Leeflang, L., 1999. Are stoloniferous plants able to avoid neighbours in response to low R: FR ratios in reflected light? Plant Ecol. 141, 59-65.

Lei, N., Li, J., Ni, S., Chen, J., 2014. Effects of clonal integration on microbial community composition and processes in the rhizosphere of the stoloniferous herb Glechoma longituba (Nakai) Kuprian. PlosOne 9, e108259.

Leme da Cunha, N., Fischer, E., Lorenz-Lemke, A.P., Barrett, S.C.H., 2014. Floral variation and environmental heterogeneity in a tristylous clonal aquatic of the Pantanal wetlands of Brazil. Ann. Bot. 114, 1637-1649.

Li, B., Shibuya, T., Yogo, Y., Hara, T., 2004. Effects of ramet clipping and nutrient availability on growth and biomass allocation of yellow nutsedge. Ecol. Res. 19, 603-612.

Li, J.H., Li, Z.Q., Ren, J.Z., 2005. Effect of grazing intensity on clonal morphological plasticity and biomass allocation patterns of Artemisia frigida and Potentilla acaulis in the Inner Mongolia steppe. N. Z. J. Agric. Res. 48, 57-61.

Liao, W.-J., Harder, L.D., 2014. Consequences of multiple inflorescences and clonality for pollinator behavior and plant mating. Am. Nat. 184, 580-592.

Liu, H.-D., Yu, F.-H., He, W.-M., Chu, Y., Dong, M., 2007. Are clonal plants more tolerant to grazing than co-occurring non-clonal plants in inland dunes? Ecol. Res. 22, 502-506.

Liu, H.-D., Yu, F.-H., He, W.-M., Chu, Y., Dong, M., 2009. Clonal integration improves compensatory growth in heavily grazed ramet populations of two inland-dune grasses. Flora 204, 298-305.

Lobo, J.A., Ramos, D.D.L., Braga, A.C., 2016. Visitation rate of pollinators and nectar robbers to the flowers and inflorescences of Tabebuia aurea (Bignoniaceae): effects of floral display size and habitat fragmentation. Bot. J. Linnean Soc. 181, 667-681.

Lopez-Garcia, A., Azcon-Aguilar, C., Barea, J., 2014. The interactions between plant life form and fungal traits of arbuscular mycorrhizal fungi determine the symbiotic community. Oecologia, 176: 1075-1086. 
Loreau, M., Naeem, S., Inchausti, P., Bengtsson, J., Grime, J.P., Hector, A., Hooper, D.U., Huston, M.A., Raffaelli, D., Schmid, B., Tilman, D., Wardle, D.A., 2001. Biodiversity and ecosystem functioning: current knowledge and future challenges. Science 294, 804-808.

Louâpre, P., Bittebiere, A.-K., Clément, B., Pierre, J.-S., Mony, C., 2012. How past and present influence the foraging of clonal plants. PLoS ONE 7, e38288.

Lovett Doust, L.L., 1981. Population dynamics and local specialization in a clonal perennial (Ranunculus repens): I. The Dynamics of ramets in contrasting habitats. J. Ecol. 69, 743-755. Lundberg, D.S., Lebeis, S.L., Herrera Paredes, S., Yourstone, S., et al., 2012. Defining the core Arabidopsis thaliana root microbiome. Nature 488, 86-90.

MacArthur, R., Levins, R., 1967. The limiting similarity, convergence, and divergence of coexisting species. Am. Nat. 101, 377-385.

Mack, R.N., Harper, J.L., 1977. Interference in dune annuals: Spatial pattern and neighbourhood effects. J. Ecol. 65, 345-363.

Manter, D.K., Delgado, J.A.; Holm, D.G., Stong, R.A., 2010. Pyrosequencing reveals of highly diverse and cultivar-specific bacterial endophyte community in potato roots. Microb. Ecol. 60, 157-166.

Marcuvitz, S., Turkington, R., 2000. Differential effects of light quality, provided by different grass neighbours, on the growth and morphology of Trifolium repens L. (white clover). Oecologia 125, 293-300.

Martinez-Garcia, L.B., Pugnaire, F.I., 2011. Arbuscular mycorrhizal fungi host preference and site effects in two plant species in a semiarid environment. App. Soil Ecol. 48, 313-317.

McCormick, A.C., Unsicker, S.B., Gershenzon, J., 2012. The specificity of herbivore-induced plant volatiles in attracting herbivore enemies. Trends Plant Sci. 17, 303-310.

McCrea, K.D., Abrahamson, W.G., 1985. Evolutionary impacts of the goldenrod ball gallmaker on Solidago altisima clones. Oecologia 68, 20-22.

McKey, D., 1974. Adaptive patterns in alkaloid physiology. Am. Nat. 108, 305-320.

Mei, C., Flinn, B.S., 2010. The use of beneficial microbial endophytes for plant biomass and stress tolerance improvement. Recent Pat. Biotechnol. 4, 81-95.

Milchunas, D., Sala, O., Lauenroth, W., 1988. A generalized-model of the effects of grazing by large herbivores on grassland community structure. Am. Nat. 132, 87-106.

Milchunas, D.G., Noy-Meir, I., 2002. Grazing refuges, external avoidance of herbivory and plant diversity. Oikos 99, 113-130. 
Moen, J., Ingvarsson, P.K., Walton, D.W.H., 1999. Estimates of structural complexity in clonal plant morphology: comparisons of grazed and ungrazed Acaena magellanica rhizomes. Can. J. Bot.-Rev. Can. Bot. 77, 869-876.

Moen, J., Walton, D.W.H., 1996. Biomass allocation in a subantarctic clonal plant (Acaena magellanica) under grazing by introduced reindeer. Antarct. Sci. 8, 147-154.

Mohammad-Esmaeili, M., Bonis, A., Bouzille, J.-B., Mony, C., Benot, M.-L., 2009. Consequence of ramet defoliation on plant clonal propagation and biomass allocation: Example of five rhizomatous grassland species. Flora 204, 25-33.

Moora, M., Öpik, M., Zobel, K., Zobel, M., 2009. Understory plant diversity is related to higher variability of vegetative mobility of coexisting species. Oecologia 159, 355-361.

Murrell, D.J., Purves, D.W., Law, R., 2001. Uniting pattern and process in plant ecology. Trends Ecol. Evol. 16, 529-530.

Novoplansky, A., 2009. Picking battles wisely: plant behavior under competition. Plant, Cell, Environ. 32, 726-741.

Oborny, B., Cain, M., 1997. Models of spatial spread and foraging in clonal plants, in: de Kroon, H., van Groenendael, J. (Eds.), The ecology and evolution of clonal plants. Backhuys Publishers, Leiden, pp. 155-183.

Oborny, B., Czaran, T., Kun, A., 2001. Exploration and exploitation of resource patches by clonal growth: a spatial model on the effect of transport between modules. Ecol. Model. 141, 151-169.

Oborny, B., Kun, A., Czaran, T., Bokros, S., 2000. The effect of clonal integration on plant competition for mosaic habitat space. Ecology 81, 3291-3304.

Olejniczak, P., Lembicz, M., 2007. Age-specific response of the grass Puccinellia distans to the presence of a fungal endophyte. Oecologia 152, 385-494.

Olff, H., Ritchie, M.E., 1998. Effects of herbivores on grassland plant diversity. Trends Ecol. Evol. 13, 261-265.

Ott, J.R., Real, L.A., Silverfine, E.M., 1985. The effect of nectar variance on bumblebee patterns of movement and potential gene dispersal. Oikos 45, 333-340.

Otway, S.J., Hector, A., Lawton, J.H., 2005. Resource dilution effects on specialist insect herbivores in a grassland biodiversity experiment. J. Anim. Ecol. 74, 234-240.

Pan, J.J., Price, J.S., 2002. Fitness and evolution in clonal plants: the impact of clonal growth. Evol. Ecol. 15, 583-600. 
Petanidou, T., Kallimanis, A.S., Tzanopoulos, J., Sgardelis, S.P., Pantis, J.D., 2008. Long-term observation of a pollination network: fluctuation in species and interactions, relative invariance of network structure and implications for estimates of specialization. Ecol. Lett. 11, 564-575. Pieterse, C.M.J., Dicke, M., 2007. Plant interactions with microbes and insects: from molecular mechanisms to ecology. Trends Plant Sci. 12, 564-569.

Piqueras, J., 1999a. Herbivory and ramet performance in the clonal herb Trientalis europaea L. J. Ecol. 87, 450-460.

Piqueras, J., 1999b. Infection of Trientalis europaea by the systemic smut fungus Urocystis trientalis: disease incidence, transmission and effects on performance of host ramets. J. Ecol. 87, 996-1004.

Piqueras, J., Klimeš, L., 1998. Demography and modelling of clonal fragments in the pseudoannual plant Trientalis europeae L.. Plant Ecol. 136, 213-227.

Piquot, Y., Petit, D., Valero, M., Cuguen, J., de Laguerie, P., Vernet, P., 1998. Variation in sexual and asexual reproduction among young and old populations of the perennial macrophyte Sparganium erectum. Oikos 82, 139-148.

Pottier, J., Evette, A., 2010. On the relationship between clonal traits and small-scale spatial patterns of three dominant grasses and its consequences on community diversity. Folia Geobot. $45,59-75$.

Price, E. A. C., Marshall, C., 1999. Clonal plants and environmental heterogeneity. An introduction to the proceedings. Plant Ecol. 141, 3-7.

Price, E.A.C., Hutchings, M.J., 1992. Studies of growth in the clonal herb Glechoma hederacea. II. The effects of selective defoliation. J. Ecol. 80, 39-47.

Price, E.A.C., Hutchings, M.J., 1996. The effects of competition on growth and form in Glechoma hederacea. Oikos 75, 279-290.

Price, E.A.C., Marshall, C., 1999. Clonal plants and environmental heterogeneity - An introduction to the proceedings. Plant Ecol. 141, 3-7.

Proulx, S.R., Promislow, D.E.L., Phillips, P.C., 2005. Network thinking in ecology and evolution. Trends Ecol. Evol. 20, 345-353.

Rapport, D.J., 1980. Optimal foraging for complementary resources. Am. Nat. 116, 324-346.

Real L.A., 1981. Nectar availability and bee-foraging on Ipomoea (Convolvulaceae). Biotropica $13,64-69$.

Rillig, M.C., Aguilar- Trigueros, C.A., Bergmann, J., Verbruggen, E., Veresoglou, S.D., Lehmann, A., 2015. Plant root and mycorrhizal fungal traits for understanding soil aggregation. New Phytol. 205, 1385-1388. 
Root, R., 1973. Organization of a plant-arthropod association in simple and diverse habitats Fauna of collards (Brassica oleracea). Ecol. Monogr. 43, 95-120.

Saikkonnen, K., Faeth, S.H., Helander, M., Sullivan, T.J., 1998. Fungal endophytes: a continuum of interactions with host plants. Ann. Rev. Ecol. Syst. 29, 319-343.

Saiz, H., Bittebiere, A.-K., Benot, M.-L., Jung, V., Mony, C., 2016. Understanding clonal plant competition for space over time: a fine-scale spatial approach based on experimental communities. J. Veg. Sci. 27, 759-770.

Sakai, Y., Takada, T., 2016. Pathogen propagation model with superinfection in vegetatively propagated plants on lattice space. PlosOne 11, e0154883.

Sammul, M., Kull, K., Tamm, A., 2003. Clonal growth in a species-rich grassland: Results of a 20-year fertilization experiment. Folia Geobot. 38, 1-20.

Schlaeppi, K., Dombrowski, N., Garrido Oter, R., ver Loren van Themaat, E., Schulze-Leferrt, P., 2014. Quantitative divergence of the bacterial root microbiota in Arabidopsis thaliana relatives. PNAS 111, 585-592.

Schmid, B., Harper, J.L., 1985. Clonal growth in grassland perennials: I. Density and patterndependent competition between plants with different growth forms. J. Ecol. 73, 793-808.

Schwinning, S., Weiner, J., 1998. Mechanisms determining the degree of size asymmetry in competition among plants. Oecologia 113, 447-455.

Scobie, A.R., Wilcock, C.C., 2009. Limited mate availability decreases reproductive success of fragmented populations of Linnaea borealis, a rare, clonal self-incompatible plant. Ann. Bot. $103,835-846$.

Seifan, M., Hoch, E.-M., Hanoteaux, S., Tielboerger, K., 2014. The outcome of shared pollination services is affected by the density and spatial pattern of an attractive neighbour. J. Ecol. 102, 953-962.

Semchenko, M., Abakumova, M., Lepik, A., Zobel, K., 2013. Plants are least suppressed by their frequent neighbours: the relationship between competitive ability and spatial aggregation patterns. J. Ecol. 101, 1313-1321.

Severns, P.M., Liston, A., Wilson, M.V., 2011. Implications of nonadventitious rhizome spread on reproduction, inbreeding, and conservation for a rare grassland legume. J. Hered. 102, 371379.

Silander, J.A., Pacala, S.W., 1985. Neighborhood predictors of plant performance. Oecologia 66, 256-263.

Silvertown, J., Smith, B., 1989. Mapping the environment for seed germination in the field. Annals Bot. 63, 163-167. 
Slade, A.J., Hutchings, M.J., 1987. The effects of light intensity on foraging in the clonal herb Glechoma hederacea. J. Ecol. 75, 639-650.

Smith, S E, Read, D J., 2008. Mycorrhizal symbioses. Third edition. Academic Press: London. Stöcklin, J., Winkler, E., 2004. Optimum reproduction and dispersal strategies of a clonal plant in a metapopulation: a simulation study with Hieracium pilosella. Evol. Ecol. 18, 563-584.

Stoll, P., Prati, D., 2001. Intraspecific aggregation alters competitive interactions in experimental plant communities. Ecology 82, 319-327.

Strauss, S.Y., Agrawal, A.A., 1999. The ecology and evolution of plant tolerance to herbivory. Trends Ecol. Evol. 14, 179-185.

Streitwolf-Engel, R., Boller, T., Wiemken, A., Sanders, I.R., 1997. Clonal growth traits of two Prunella species are determined by co-occurring arbuscular mycorrhizal fungi from a calcareous grassland. J. Ecol. 85, 181-191.

Streitwolf-Engel, R., van der Heijden, M. G. A., Sanders, I. R., 2001. The ecological significance of arbuscular mycorrhizal fungal effects on clonal reproduction in plants. Ecology $82,2846-2859$.

Stuefer, J.F., 1998. Two types of division of labour in clonal plants: benefits, costs and constraints. Perspect. Plant Ecol. Evol. Syst. 1, 47-60.

Stuefer, J.F., During, H.J., de Kroon, H., 1994. High benefits of clonal integration in two stoloniferous species, in response to heterogeneous light environments. J. Ecol. 82, 511-518.

Stuefer, J.F., Gómez, S., Van Molken, T., 2004. Clonal integration beyond resource sharing: implications for defence signalling and disease transmission in clonal plant networks. Evol. Ecol. 18, 647-667.

Stuefer, J.F., Huber, H., 1999. The role of stolon internodes for ramet survival after clone fragmentation in Potentilla anserina. Ecol. Lett. 2, 135-139.

Sudová, R., 2009. Different growth response of five co-existing stoloniferous plant species to inoculation with native arbuscular mycorrhizal fungi. Plant Ecol. 204, 135-143.

Sutherland, W.J., Stillman, R.A., 1988. The foraging tactics of plants. Oikos 52, 239-244.

Tahvanainen, J.O., Root, R.B., 1972. The influence of vegetational diversity on the population ecology of a specialized herbivore, Phyllotreta cruciferae (Coleoptera: Chrysomelidae). Oecologia 10, 321-346.

Tamm, A., Kull, K., Sammul, M., 2002. Classifying clonal growth forms based on vegetative mobility and ramet longevity: a whole community analysis. Evol. Ecol. 15, 383-401.

Thébault, E., Fontaine, C., 2010. Stability of ecological communities and the architecture of mutualistic and trophic networks. Science 329, 853-856. 
Thompson, J.D., 2001. How do visitation patterns vary among pollinators in relation to floral display and floral design in a generalist pollination system? Oecologia 126, 386-394.

Tilman, D., 1994. Competition and biodiversity in spatially structured habitats. Ecology 75, 216.

Toju, H., Guimarães, P.R., Olesen, J.M., Thompson, J.N., 2014. Assembly of complex plantfungus networks. Nature Communications 5, 5273.

Turcotte, M.M., Levine, J.M., 2016. Phenotypic plasticity and species coexistence. Trends Ecol. Evol. 31, 803-813.

Turkington, R., Hamilton, R.S., Gliddon, C., 1991. Within-population variation in localized and integrated responses of Trifolium repens to biotically patchy environments. Oecologia 86, $183-$ 192.

Turkington, R., Harper, J.L., 1979. The growth, distribution and neighbour relationships of Trifolium repens in a permanent pasture: II. Inter- and intra-specific contact. J. Ecol. 67, 219230.

Unsicker, S.B., Oswald, A., Koehler, G., Weisser, W.W., 2008. Complementarity effects through dietary mixing enhance the performance of a generalist insect herbivore. Oecologia $156,313-324$.

Vallejo-Marín, M., Dorken, M.E., Barrett, S.C.H., 2010. The ecological and evolutionary consequences of clonality for plant mating, Ann. Rev. Ecol. Evol. Syst. 41, 193-213.

Van der Heidjden, M.G.A., Bardgett, R..D., Van Straalen, N.M., 2008. The unssen majority: soil microbes as drivers of plant diversity and productivity in terrestrial ecosystems. Ecol. Lett. 11, 296-310.

van der Heijden, M., Klironomos, J., Ursic, M., Moutoglis, P., Streitwolf-Engel, R., Boller, T., Wiemken, A., Sanders, I.R., 1998. Mycorrhizal fungal diversity determines plant biodiversity, ecosystem variability and productivity. Nature 396, 69-72.

Van der Meijden, E., Wijn, M., Verkaar, H., 1988. Defense and regrowth, alternative plant strategies in the struggle against herbivores. Oikos 51, 355-363.

Van Der Putten, W.H., 2003. Plant defense belowground and spatiotemporal processes in natural vegetation. Ecology 84, 2269-2280.

Van der Putten, W.H., Macel, M., Visser, M.E., 2010. Predicting species distribution and abundance response to climate change: why it is essential to include biotic interactions across trophic levels. Phil. Trans. R. Soc. B 365, 2025-2034.

van Groenendael, J., de Kroon H., 1990. Clonal growth in plants: regulation and function. SBP Academic Publishing, The Hague. 
van Groenendael, J.M.V., Klimeš, L., Klimešová, J., Hendriks, R.J.J., 1996. Comparative ecology of clonal plants. Phil. Trans. R. Soc. B 351, 1331-1339.

Van Kleunen, M., Fisher, M., Schmid, B., 2001. Effects of intraspecific competition on size variation and reproductive allocation in a clonal plant. Oikos 94, 515-524.

Van Rossum, F., Leprince, N., Mayer, C., Raabová, J., Hans, G., Jacquemart, A.-L., 2015. What influences pollen dispersal in the clonal distylous Menyanthes trifoliata (Menyanthaceae)? Plant Ecol. Evol. 148, 199-212.

Vandenkoornhuyse, P., Husband, R., Daniell, T.J., Watson, I.J., Duck, J.M., Fitter, A.H., Young, J.P.W., 2002. Arbuscular mycorrhizal community composition associated with two plant species in a grassland ecosystem. Mol. Ecol. 11, 15555-1564.

Vandenkoornhuyse, P., Quaiser, A., Duhamel, M., Le Van, A., Dufresne, A., 2015. The importance of the microbiome of the plant holobiont. New Phytologist 206, 1196-1206.

Vandenkoornhuyse, P., Ridgway, K.P., Watson, I.J., Fitter, A.H., Young, J.P.W., 2003. Coexisting grass species have distinctive arbuscular mycorrhizal communities. Mol. Ecol. 12, 3085-3095.

Vannier, N., Bittebiere, A.-K., Vandenkoornhuyse, P., Mony, C., 2016. A fungi patchiness and the clonal growth of Glechoma hederacea in heterogeneous environments. Scientific Reports 6, 37852.

Vannier, N., Mony, C., Bittebiere, A-K, Michon-Coudouel, S, Biget, M., Vandenkoornhuyse P., 2018. A microorganims'journey between plant generations. Microbiome 6, 79.

WallisDeVries, M.F., Laca, E.A., Demment, M.W., 1999. The importance of scale of patchiness for selectivity in grazing herbivores. Oecologia 121, 355-363.

Wang, Y., Wang, Q.F., Guo, Y.H., Barrett, S.C.H., 2005. Reproductive consequences of interactions between clonal growth and sexual reproduction in Nymphoides peltata: a distylous aquatic plant. New Phytol. 165, 329-335.

Wang, Z.W., Li, L.H., Han, X.G., Ming, D., 2004. Do rhizome severing and shoot defoliation affect clonal growth of Leymus chinensis at ramet population level? Acta Oecol.-Int. J. Ecol. $26,255-260$.

Watson, M., Scott, K., Griffity, J., Dieter, S., Jones, C.S., Nanda, S., 2002. The developmental ecology of mycorrhizal associations in mayapple, Podophyllum peltatum, Berberidaceae., Evol. Ecol. 15, 425-442.

Weijschedé, J., Berentsen, R., de Kroon, H., Huber, H., 2008. Variation in petiole and internode length affects plant performance in Trifolium repens under opposing selection regimes. Evol. Ecol. 22, 383-397. 
Wennstrom, A., Ericson, L., 1992. Environmental heterogeneity and disease transmission within clones of Lactuca sibirica. J. Ecol. 80, 71-77.

White, J.A., Whitham, T.G., 2000. Associational Susceptibility of Cottonwood to a Box Elder Herbivore. Ecology 81, 1795-1803.

Wildová, R., Wild, J., Herben, T., 2007. Fine-scale dynamics of rhizomes in a grassland community. Ecography 30, 264-276.

Wilsey, B., 2002. Clonal plants in a spatially heterogeneous environment: effects of integration on Serengeti grassland response to defoliation and urine-hits from grazing mammals. Plant Ecol. 159, 15-22.

Wilson, A.S.G., van der Kamp, B.J., Ritland, C., 2005. Opportunities for geitonogamy in the clonal herb Maianthemum dilatatum. Can. J. Bot. 83, 1082-1087.

Wolf, A.T., Harrison, S.P., 2001. Effects of habitat size and patch isolation on reproductive success of the serpentine morning glory. Conserv. Biol. 15, 111-121.

Wolfe, B.E., Husband, B.C., Klironomis, N., 2005. Effects of a belowground mutualism on an aboveground mutualism. Ecol. Lett. 8, 218-223.

Yamamura, K., 2002. Biodiversity and stability of herbivore populations: influences of the spatial sparseness of food plants. Popul. Ecol. 44, 33-40.

Yang, H., Zang, Y., Yuan, Y., Tang, J., Chen, X., 2012. Selectivity by host plants affects the distribution of arbuscular mycorrhizal fungi: evidence from ITS rDNA sequence metadata. BMC Evol. Biol. 12, 50-62.

Young, A.G., Broadhurst, L.M., Thrall, P.H., 2012. Non-additive effects of pollen limitation and self-incompatibility reduce plant reproductive success and population viability. Ann. Bot. 109, 643-653.

Zobel, K., 2008. On the forces that govern clonality versus sexuality in plant communities. Evol. Ecol. 22, 487-492.

Zobel, M., Moora, M., Herben, T., 2010. Clonal mobility and its implications for spatiotemporal patterns of plant communities: what do we need to know next? Oikos 119, 802-806. 


\section{Box 1. Definitions of the biotic interactions and response strategies investigated in this study}

\section{Types of interaction}

Competition: antagonist plant-plant interaction caused by a shared need for a limited resource (light, water, nutrients), being detrimental to at least one of the interacting plants (Begon et al., 1996).

Facilitation: positive plant-plant interactions that benefit at least one of the interacting plants (Bruno et al., 2003).

Herbivory: interactions in which a consumer (herbivore) benefits from a resource (plant) at its expense. Herbivory encompasses a wide range of animal taxa and can affect all plant organs e.g. stems, roots, flowers (florivory), fruits (frugivory) or seeds (Huntly 1991, Johnson et al. 1997).

Mutualism: interspecific interactions that benefit both partners, from obligate to generalized associations (Bronstein 1994), including e.g. interactions with pollinators or micro-organisms. Pollination interactions: mutualistic interactions in which the pollinator benefits from floral resources and the plant benefits from pollen transfer. Diverse animal taxa can act as pollinators among which insects are the most often involved (Kearns et al. 1998).

Parasitism: interactions in which a consumer (parasite) benefits from a resource (host plant) at the plant's expense. Contrary to herbivory, parasitism is generally a long-lasting interaction (Johnson et al. 1997).

Plant - pathogen interactions: interactions in which a partner (pathogen) generates a disease in another partner (host plant).

\section{Plant response strategies to antagonist interactions}

Avoidance: mechanisms that reducing the probability or intensity of antagonist interactions. Avoidance can rely on deterrents (defenses), plant traits that decrease detectability or accessibility (spatial avoidance), or phenological traits (temporal avoidance) (adapted from Briske, 1996).

Defense: mechanisms of repulsion of the antagonists, which mostly rely on anatomical, morphological or biochemical traits (adapted from Stuefer et al., 2004).

Tolerance: mechanisms that enable a plant to maximize growth and reproduction under the worsened conditions caused by antagonist interactions (adapted from Novoplansky, 2009). 


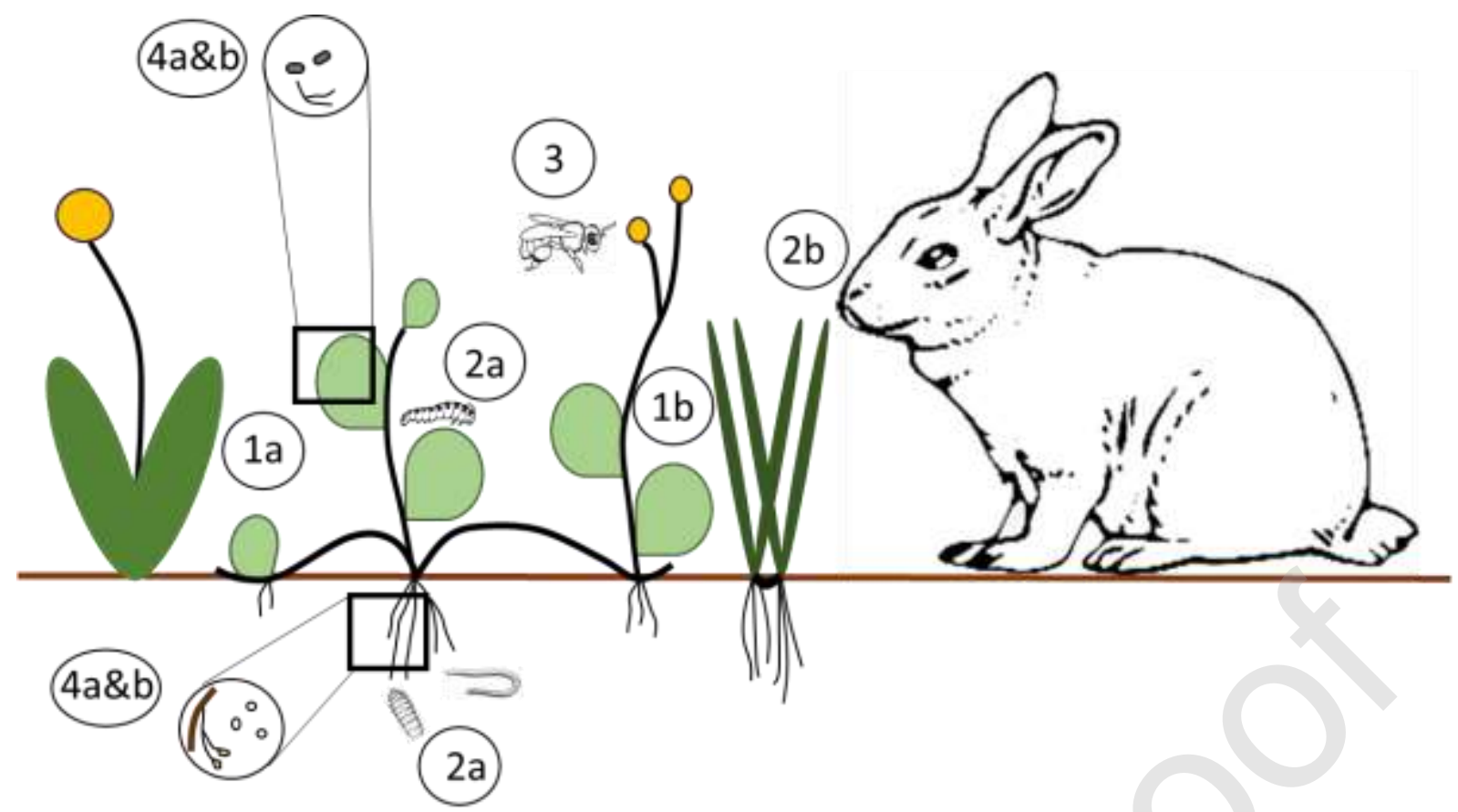

Figure 1. Synthesis of the biotic interactions involving a particular clonal plant. 1) plant-plant interaction, 1a. between clonal and non-clonal plants, 1b. between two clonal plants; 2) plantherbivore interaction, $2 \mathrm{a}$. aboveground and belowground microherbivory, 2b. macroherbivory; 3) plant-pollinator interaction, 4) plant-microorganism interaction, a. mutualist, b. pathogenic. 


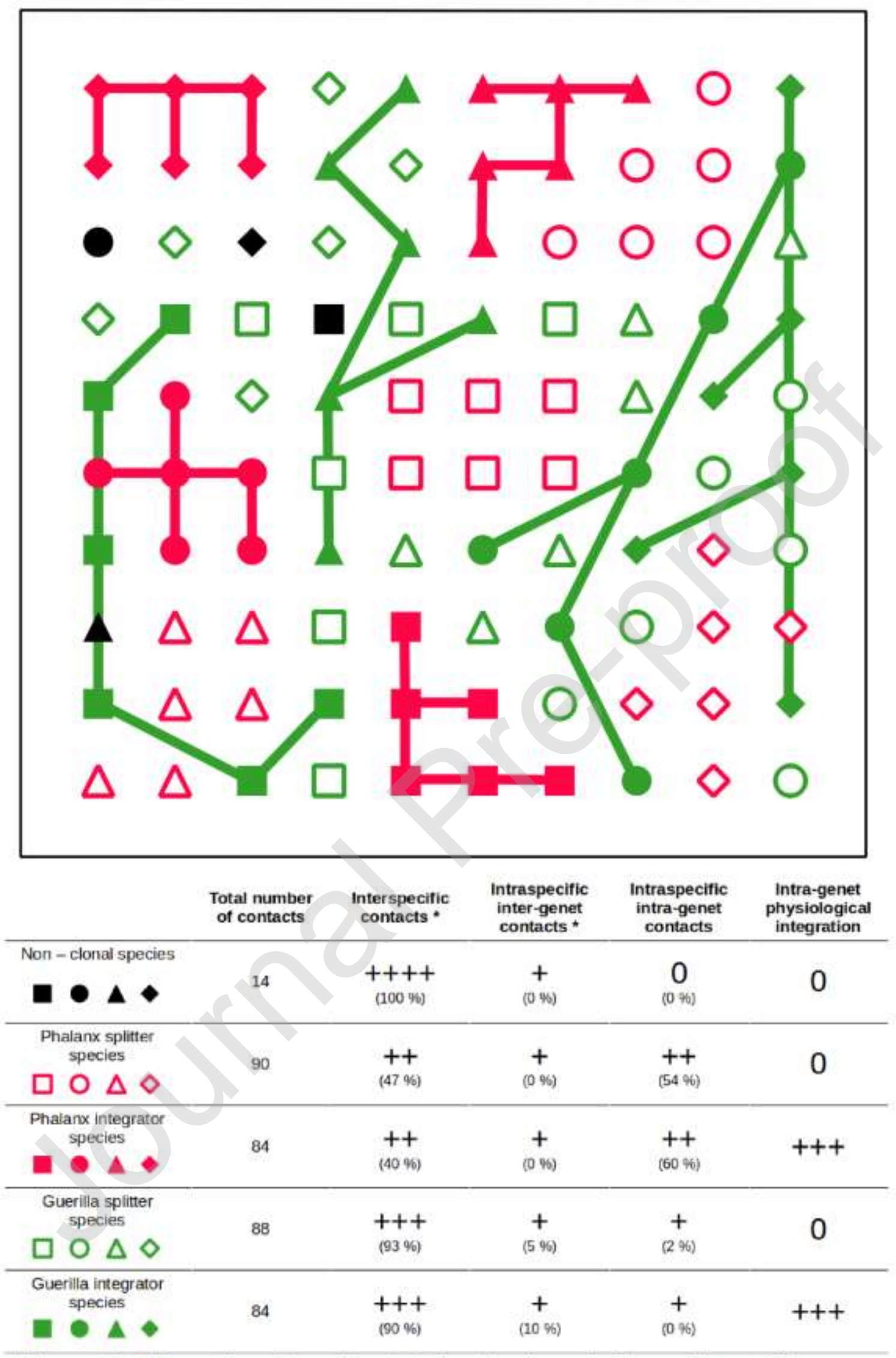

- The proportion of interspecific vs. intraspecific contacts depends on the species richness of the assemblage. 
Figure 2. Schematic representation of a plant assemblage composed of 100 ramets belonging to five species representative of five strategies: non-clonal species (solid black symbols), phalanx splitter species (empty red symbols), phalanx integrator species (solid red symbols), guerilla splitter species (empty green symbols) and guerilla integrator species (solid green symbols). Each species is represented by four genets (different symbols). For the non-clonal species, each genet is composed of a single ramet (four ramets in all). For clonal species, each genet contains six ramets ( 24 ramets in all for each species). The solid lines between ramets represent connections (integrator species). Depending on its position, each ramet is surrounded by two to four neighbors, a neighbor being a side ramet. For each species, the table lists the total number of contacts between each ramet and its neighbors. The expected range of contacts with ramets belonging to (i) another species, (ii) the same species but another genet or (iii) the same genet as well as (iv) the importance of physiological integration are shown $(0,+,++$, $+++)$. For each type of contact, the corresponding value (\%) in the schematic assemblage is given in parentheses. 


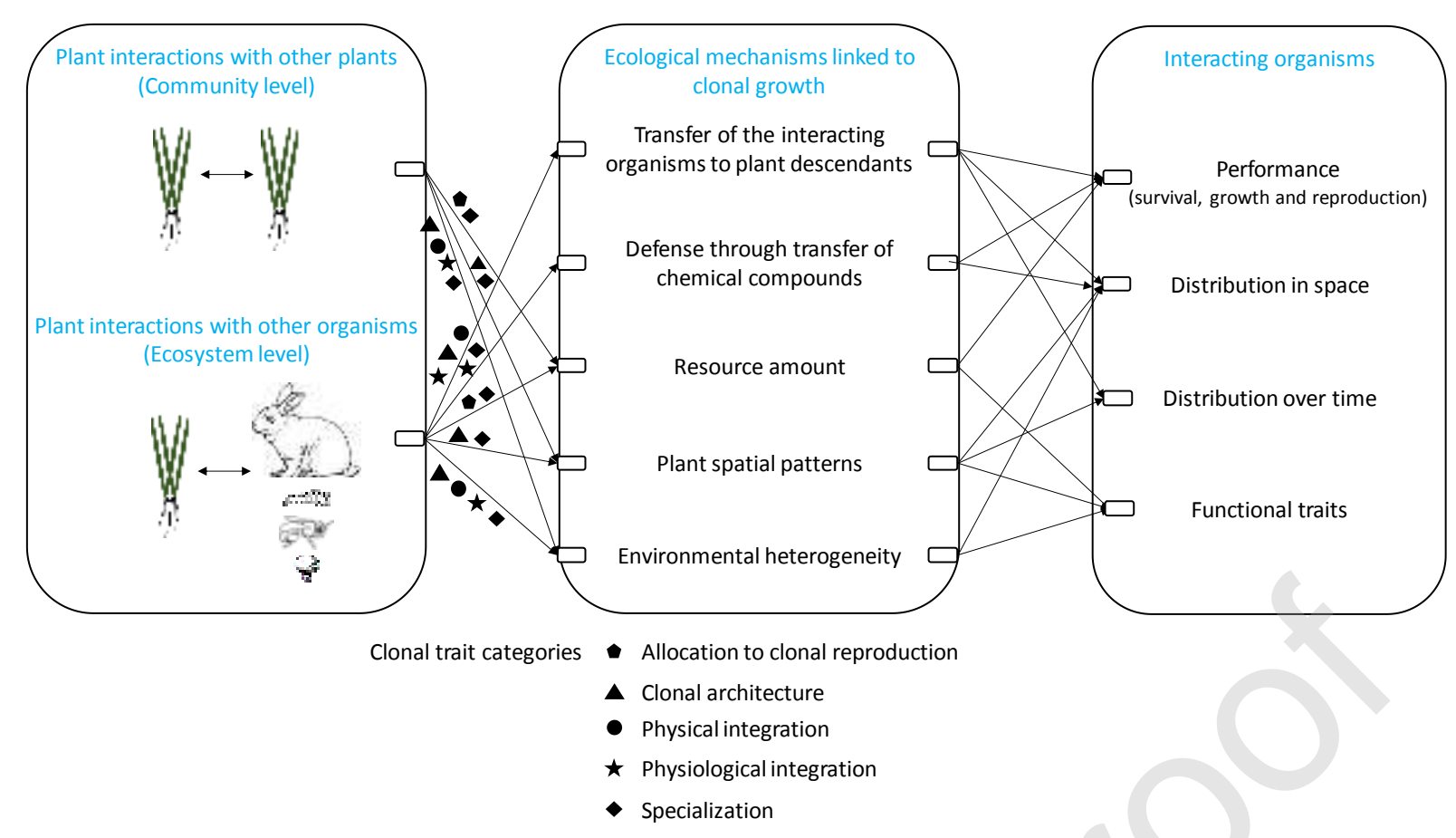

Figure 3. Effects of clonality on the performance, the distribution in space and over time, and the traits of the interacting organism. The arrows indicate (i) the influence of interactions on the ecological mechanisms linked to clonal growth, and (ii) the consequences for the interacting organisms. The categories of clonal traits involved in the underlying mechanisms, are presented with different geometrical forms. 


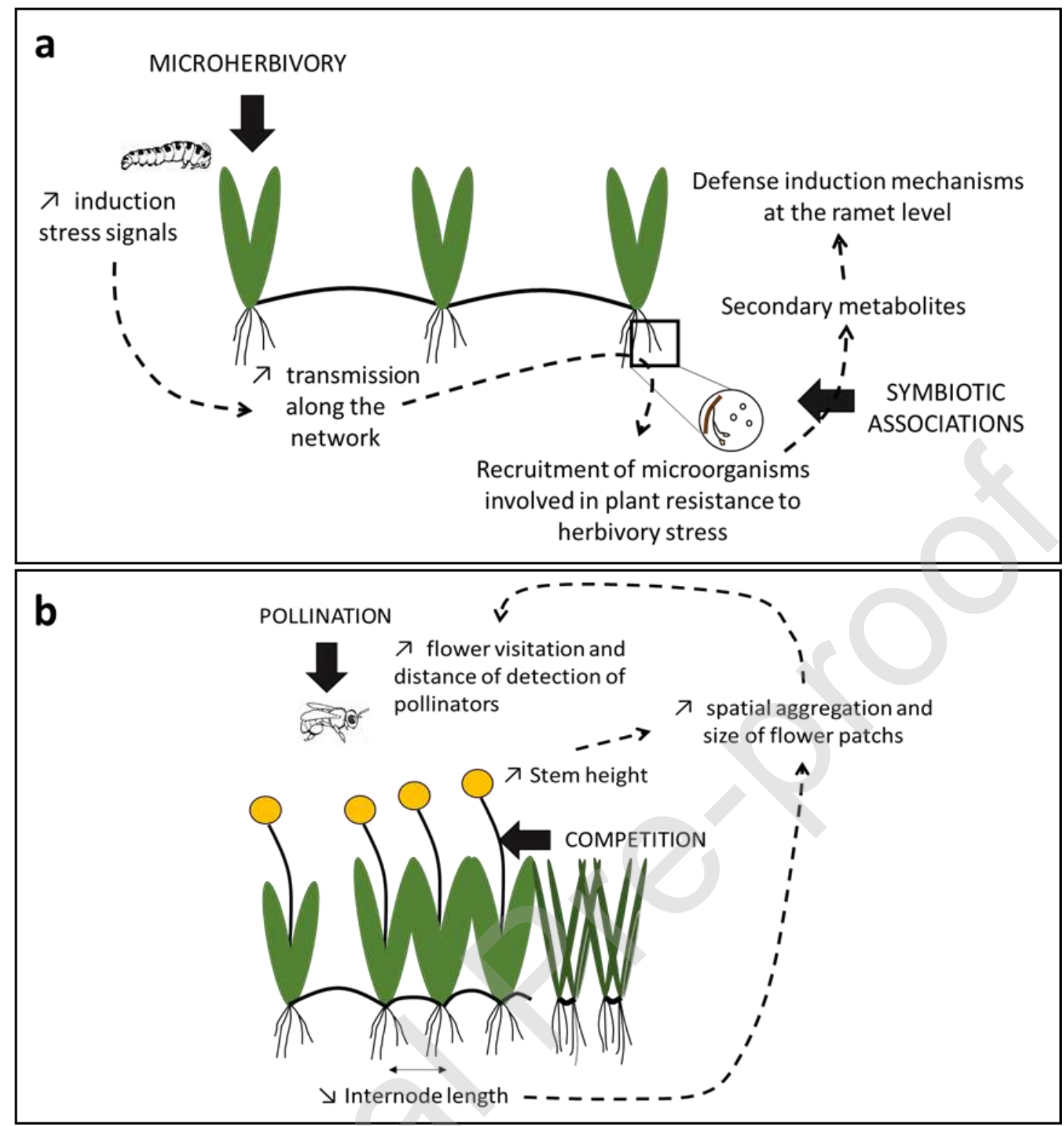

Figure 4. Hypothetical examples of the role (effect and response) of clonal plant traits in multitrophic level interactions. (a) plant-herbivore and plant-microorganism interactions: micro-herbivore attacks trigger a response in clonal plants that modifies the recruitment of microorganisms, thereby generating a defense mechanism; (b) plant-plant and plant-pollinator interactions: competition affects ramet spatial distribution, which has an effect on pollinator behavior. 
Table 1. What are the specificities of clonal plant response to negative interactions? We suggested hypotheses (in grey) of the particular role of clonality compared to non-clonal plants in their response to negative interactions, as well as the theoretical underlying mechanisms. For each interaction, we specified (i) whether the literature supports the theoretical mechanism (in brackets), (ii) how many publications were used (in square brackets, the star indicating that some of these publications are based on modelling approaches), and (iii) what is actually observed according to the literature. $/=$ no literature supports; $0=$ clonality is not explicitly taken into account; -- $=0-25 \%$ of publications support the theoretical mechanism; - $=25-50 \%$ of publications support the theoretical mechanism; ? = as many publications support or do not support the theoretical mechanism; $+=50-75 \%$ of publications support the theoretical mechanism; $++=75-100 \%$ of publications support the theoretical mechanism.

\begin{tabular}{|c|c|c|c|}
\hline \multirow[t]{2}{*}{$\begin{array}{c}\text { Theoretical underlying mechanism } \\
\text { related to clonality }\end{array}$} & \multicolumn{3}{|c|}{ Literature observations } \\
\hline & Competition & Herbivory & Pathogens \\
\hline \multicolumn{4}{|c|}{ SPATIAL AVOIDANCE: Clonal organs would allow the plant to horizontally escape from harmful conditions, and quicker than through sexual reproduction. } \\
\hline High clonal mobility & $\begin{array}{l}(++)\left[3 \mathrm{R}^{*}\right] \\
\text { Plant grows in the direction of least } \\
\text { interferences }\end{array}$ & $\begin{array}{l}(--)[6 \mathrm{R}] \\
\text { Internode or connection length decreases } \\
\text { in response to aboveground herbivory }\end{array}$ & / \\
\hline $\begin{array}{l}\text { Increased clonal multiplication and } \\
\text { lower seed production }\end{array}$ & $\begin{array}{l}\text { (--) [1R] } \\
\text { Allocation to sexual reproduction } \\
\text { increases more than allocation to } \\
\text { clonal growth under higher } \\
\text { competitive density }\end{array}$ & 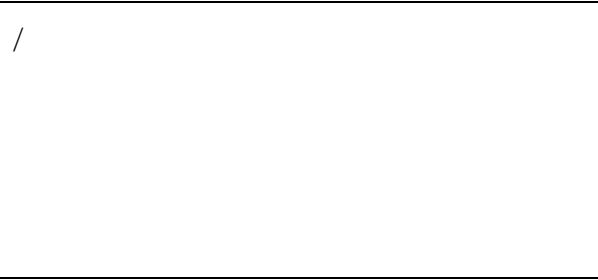 & $\begin{array}{l}\text { (0) [4R] } \\
\text { Seed production actually lowers the } \\
\text { spread of pathogens as this spread usually } \\
\text { occurs through vegetative organs. Most } \\
\text { fungi pathogen cannot be transmitted } \\
\text { through seeds }\end{array}$ \\
\hline $\begin{array}{l}\text { Physiological integration: detection of } \\
\text { the heterogeneity in the antagonistic } \\
\text { organism distribution }\end{array}$ & $\begin{array}{l}(++)[2 \mathrm{R}] \\
\text { Signal spreading across the clonal } \\
\text { fragment indicates the presence of } \\
\text { competitors }\end{array}$ & I & l \\
\hline Clonal organs optimal positioning & $\begin{array}{l}(++)\left[3 \mathrm{R}^{*}\right] \\
\text { The plant positions its ramets within } \\
\text { the less densely occupied patches } \\
\text { (foraging in the horizontal direction) }\end{array}$ & $\begin{array}{l}(?)[1 \mathrm{R}] \\
\text { Whether below-ground clonal organs } \\
\text { contribute to escaping from aboveground } \\
\text { herbivory is unclear }\end{array}$ & I \\
\hline
\end{tabular}




\begin{tabular}{|c|c|c|c|}
\hline $\begin{array}{l}\text { Physiological integration: defense } \\
\text { signals sharing through connections }\end{array}$ & I & $\begin{array}{l}(++)[3 R] \\
\text { Translocation of defense signals through } \\
\text { connections induces defense response of } \\
\text { younger, more valuable ramets }\end{array}$ & I \\
\hline Ramet specialization & ( & $\begin{array}{l}(-)[3 R] \\
\text { Defenses are not necessarily allocated to } \\
\text { most valuable ramets in terms of future } \\
\text { sexual reproduction }\end{array}$ & ( \\
\hline \multicolumn{4}{|c|}{$\begin{array}{l}\text { TOLERANCE: Specific clonal properties and organs would allow faster and more efficient production of biomass and descendants in the worst conditions caused by } \\
\text { antagonist interactions }\end{array}$} \\
\hline $\begin{array}{l}\text { Increased investment in clonal } \\
\text { multiplication }\end{array}$ & $\begin{array}{l}(--)[2 \mathrm{R}] \\
\text { Regulation of ramet birth or death to } \\
\text { limit intraclonal competition (limit } \\
\text { ramet density) }\end{array}$ & $\begin{array}{l}(-)[6 R] \\
\text { CMR shows contrasted responses to } \\
\text { herbivory (mostly decreases or no } \\
\text { changes) }\end{array}$ & l \\
\hline $\begin{array}{l}\text { Physical integration: increase in } \\
\text { connection lifespan }\end{array}$ & $\begin{array}{l}(++)\left[2 R^{*}\right] \\
\text { The fine-scale heterogeneity } \\
\text { generated by competition favors } \\
\text { integrated species }\end{array}$ & $\begin{array}{l}\text { (?) [1R] } \\
\text { Both short belowground (a priori long- } \\
\text { lived) and short-lived aboveground } \\
\text { connections dominate vegetation in grazed } \\
\text { grasslands }\end{array}$ & $\begin{array}{l}\text { (?) }\left[2 \mathrm{R}^{*}\right] \\
\text { Low connection lifespan lowers the } \\
\text { spread of pathogens along connections }\end{array}$ \\
\hline $\begin{array}{l}\text { Physiological integration: discrepancy in } \\
\text { the clonal fragment and ramet lifespans }\end{array}$ & $\begin{array}{l}(++)[2 \mathrm{R}] \\
\text { Past and present competitive } \\
\text { interactions of the fragment are } \\
\text { involved in ramet response }\end{array}$ & I & I \\
\hline $\begin{array}{l}\text { Physiological integration: integration of } \\
\text { the response on the whole clone }\end{array}$ & $\begin{array}{l}(++)[2 \mathrm{R}] \\
\text { Ramet response is averaged relatively } \\
\text { to all neighborhoods perceived by the } \\
\text { other connected ramets }\end{array}$ & / & / \\
\hline $\begin{array}{l}\text { Physiological integration: resource } \\
\text { sharing towards ramets facing negative } \\
\text { interactions }\end{array}$ & $\begin{array}{l}(++)[3 \mathrm{R}] \\
\text { Translocation of resources supports } \\
\text { ramet growth }\end{array}$ & $\begin{array}{l}(-)[4 \mathrm{R}] \\
\text { Intact connections allowing translocation } \\
\text { of resources from undamaged ramets } \\
\text { mostly have no effect on response to } \\
\text { herbivory }\end{array}$ & $\begin{array}{l}(++)\left[1 \mathrm{R}^{*}\right] \\
\text { Translocation of resources supports ramet } \\
\text { growth }\end{array}$ \\
\hline Higher resource storage in clonal organs & $\begin{array}{l}(++)[2 \mathrm{R}] \\
\text { The biomass allocation to reserve } \\
\text { organs increases in competitive } \\
\text { environments. }\end{array}$ & $\begin{array}{l}(--)[5 R] \\
\text { The depletion of carbohydrate reserves or } \\
\text { the decrease in clonal storage organ }\end{array}$ & I \\
\hline
\end{tabular}




\begin{tabular}{|c|c|c|}
\hline & & $\begin{array}{l}\text { biomass in response to herbivory rarely } \\
\text { support compensatory growth } \\
\text { (?) [1R] } \\
\text { Investment in clonal storage organs is not } \\
\text { necessarily favored in environments with } \\
\text { a high risk of herbivory }\end{array}$ \\
\hline
\end{tabular}


Table 2. What are the specificities of clonal plant response to positive interactions? We suggested hypotheses (in grey) of the particular role of clonality compared to non-clonal plants in their response to positive interactions, as well as the theoretical underlying mechanisms. For each interaction, we specified (i) whether the literature supports the theoretical mechanism (in brackets), (ii) how many publications were used (in square brackets), and (iii) what is actually observed according to the literature. / = no literature supports; 0 = clonality is not explicitly taken into account; $--=0-25 \%$ of publications support the theoretical mechanism; $-=25-50 \%$ of publications support the theoretical mechanism; ? $=$ as many publications support or do not support the theoretical mechanism; $+=50-75 \%$ of publications support the theoretical mechanism; $++=75-100 \%$ of publications support the theoretical mechanism.

\begin{tabular}{|c|c|c|c|c|}
\hline \multicolumn{2}{|c|}{ Theoretical underlying mechanism related to clonality } & \multicolumn{3}{|c|}{ Literature observations } \\
\hline & & Facilitation & Pollination & Fungal symbiosis \\
\hline \multicolumn{5}{|c|}{ INTERACTION MAXIMIZATION: Clonality ensures a continuity of partnership with favorable organisms } \\
\hline \multirow{4}{*}{$\begin{array}{l}\text { Promoting the interaction with } \\
\text { favorable organisms and the } \\
\text { stability of the relationship over } \\
\text { time }\end{array}$} & $\begin{array}{l}\text { Increased investment in clonal } \\
\text { multiplication }\end{array}$ & $\begin{array}{l}\text { (--) }[1 \mathrm{R}] \\
\text { No differences were found in }\end{array}$ & $(0)[5 R]$ & $(++)[1 \mathrm{R}]$ \\
\hline & & $\begin{array}{l}\text { the biomass invested in clonal } \\
\text { multiplication between plants } \\
\text { under stressed and facilitated } \\
\text { conditions }\end{array}$ & $\begin{array}{l}\text { Sexual reproduction is } \\
\text { disfavoured in clonal plants } \\
\text { when the risk of } \\
\text { geitonogamy is high, but } \\
\text { whether clonal } \\
\text { multiplication increases is } \\
\text { unknown }\end{array}$ & $\begin{array}{l}\text { Number of produced ramet is } \\
\text { stimulated in presence of } \\
\text { mutualist fungi thereby } \\
\text { increasing the amount of } \\
\text { available habitats for their } \\
\text { colonization }\end{array}$ \\
\hline & High clonal mobility & $\begin{array}{l}\text { (0) }[1 \mathrm{R}] \\
\text { Clonal mobility should favor }\end{array}$ & $(++)[1 \mathrm{R}]$ & $(++)[2 \mathrm{R}]$ \\
\hline & & $\begin{array}{l}\text { directional growth toward } \\
\text { facilitative plants }\end{array}$ & $\begin{array}{l}\text { By maximizing } \\
\text { intraspecific contacts with } \\
\text { different genets, clonal } \\
\text { mobility could increase } \\
\text { outcrossing }\end{array}$ & $\begin{array}{l}\text { Clonal mobility should be low } \\
\text { so that the plant develop at the } \\
\text { speed of the mutualists and } \\
\text { ensure a better transmission of } \\
\text { mutualists to new ramets }\end{array}$ \\
\hline $\begin{array}{l}\text { Ensuring a pseudo-vertical } \\
\text { transmission of favorable } \\
\text { organisms to daughter ramets, } \\
\text { building suitable niches for } \\
\text { them }\end{array}$ & $\begin{array}{l}\text { Physical integration: high lifespan } \\
\text { of connections }\end{array}$ & I & / & $\begin{array}{l}(++)[2 \mathrm{R}] \\
\text { Clonal integration is high to } \\
\text { transfer the mutualists to the } \\
\text { daughter ramets through } \\
\text { connections }\end{array}$ \\
\hline
\end{tabular}




\begin{tabular}{|c|c|c|c|c|c|}
\hline & $\begin{array}{l}\text { Physiological integration: buffer } \\
\text { environmental heterogeneity }\end{array}$ & 1 & & $\begin{array}{l}(++)[1 \mathrm{R}] \\
\text { Physiological integration is } \\
\text { reduced as mutualists support } \\
\text { acquisition of resources and } \\
\text { resistance to local environmental } \\
\text { stresses of ramets }\end{array}$ \\
\hline & & Optimal ramet positioning & $\begin{array}{l}\text { Clo [1R] } \\
\text { Clonal plant adaptively position } \\
\text { their ramet in the close vicinity } \\
\text { of facilitative plants }\end{array}$ & $\begin{array}{l}(-)[3 R] \\
\text { The expected advantage of } \\
\text { guerilla over phalanx } \\
\text { architecture regarding } \\
\text { geitonogamy depends on } \\
\text { the mobility and foraging } \\
\text { behavior of pollinator } \\
\text { assemblages }\end{array}$ & $\begin{array}{l}(--)[1 \mathrm{R}] \\
\text { Clonal plants optimize their } \\
\text { ramet positioning, settling in } \\
\text { patches with mutualists and } \\
\text { escaping from patches where } \\
\text { there are no mutualist fungi }\end{array}$ \\
\hline & & Specialization of ramets & 1 & I & $\begin{array}{l}(++)[1 \mathrm{R}] \\
\text { Ramet specialization is less } \\
\text { pronounced in presence of } \\
\text { mutualists as they buffer } \\
\text { environmental heterogeneity }\end{array}$ \\
\hline
\end{tabular}

